\title{
28 Research Square \\ Morphological and genetic diversity of traditional varieties of agave in Hidalgo State, Mexico
}

Carmen Julia Figueredo-Urbina ( $\nabla$ figueredocj@gmail.com )

Universidad Autonoma del Estado de Hidalgo https://orcid.org/0000-0003-0906-8821

\section{Gonzalo D. Álvarez-Ríos}

UNAM

Mario Adolfo García-Montes

UAEH: Universidad Autonoma del Estado de Hidalgo

Pablo Octavio-Aguilar

UAEH: Universidad Autonoma del Estado de Hidalgo

\section{Research}

Keywords: human-agave symbiosis, traditional knowledge, agrobiodiversity, pulque agave

Posted Date: January 14th, 2021

DOI: https://doi.org/10.21203/rs.3.rs-143808/v1

License: (c) (i) This work is licensed under a Creative Commons Attribution 4.0 International License. Read Full License 


\section{Abstract}

Background: The agaves are plants of cultural importance that have been used by humans for about 10,000 years for about 40 specific uses, of which the most culturally and economically important are fermented (Pulque) and distilled beverages (Mescal). Pulque continues to be produced in nearly all of Mexico, and the agaves used for this propose have shown domestication syndrome and selected morphological characteristics, such as larger plant size (since size is positively related to sap production) and less dentition of the leaves.

Methods: In this study, we carry out an ethnobotanical, morphological and genetic analysis of the traditional varieties of pulque agave used in the production of aguamiel (agave sap) and pulque in two localities of the state of Hidalgo. We did semi-structured interviews and tours with crop owners, tlachiqueros (sap harvesters), and people related to the production system. We analyzed the morphology of 111 plants, and we studied the diversity and genetic structure of 130 individuals using 16 nuclear microsatellites.

Results: We found wild, tolerated, transplanted, and cultivated varieties of agave. Asexual reproduction was the main method of propagation. We recorded 19 traditional varieties of pulque agave, 12 of them in production during the study, which correspond to the species Agave americana, A. salmiana y A. mapisaga with five intraspecific entities. The varieties were grouped according to a management gradient; the wild varieties were the smallest, with more lateral teeth and a larger terminal spine. The cultivated varieties clearly exhibited domestication syndrome, with larger plants and smaller dentition. The expected heterozygosity $(\mathrm{He})$ of the varieties ranged between 0.204 to 0.721 . Bayesian clustering suggested the existence of three genetic groups $(K=3)$, both at the level of traditional varieties of pulque agaves and for management categories, a result that matches multivariate clustering.

Conclusions: Pulque producers in the studied localities, maintain high agrobiodiversity. The cultivated varieties exhibit domestication syndrome, as has been reported for other species of the genus with the same selection purposes. Our results support the hypothesis of a decrease in genetic diversity in crops compared to wild agaves, which seems to be due to vegetative propagation, among other factors.

\section{Introduction}

Agaves are a group of monocotyledonous, rosetophilic, succulent and monocarpic plants. They were reclassified to the Asparagaceae family, but the Agavoideae subfamily continues to be recognized. The Agave genus is the richest taxon within this subfamily, with 210 species distributed from the southern United States to Colombia and Venezuela and the Caribbean Islands [1, 2, 3]. In Mexico there are 160 species (76\% of the genus), which can be found in various ecosystems, mainly arid and semi-arid areas, and in anthropogenic environments. Agaves are a pillar for the functioning of the systems where they grow due to several ecological functions such as soil retention-formation, erosion reduction, increased water infiltration, habitat, and food provision for species of insects, reptiles, birds and bats, as well as benefits for human populations $[3,4]$.

According to the morphology of their inflorescences, Gentry [5] classified the genus into two subgenera: Agave and Littaea. The greatest diversity of Agave is found in the Tehuacan-Cuicatlan Valley, shared between the states of Oaxaca and Puebla (approximately 20 species), while the area with the greatest diversity of Littaea (eight species) is in the Barranca de Metztitlán, in the state of Hidalgo [6, 7].

In the Hidalgo State, 17 Agave taxa have been reported, considering intraspecific varieties [5]. Among the total taxa, four species - Agave americana, A. lechuguilla, A. mapisaga, and A. salmiana- have been widely used for several 
purposes in the region. For example, $A$. lechuguilla is used to obtain fibers, make articles for cleaning and for bags. The other three species are mainly used for food purposes, for example: 1) flowers are collected to prepare different dishes (gualumbos), 2) the leaves (penca) and cuticle (mixiote) are used as utensils and ingredients for cooking food, 3) drinks are prepared from the sap extracted from the central corm, both fresh as aguamiel and fermented as pulque and 4) preparing mead sap (jarabe de aguamiel).

Archaeological records suggest that the use of agaves dates back at least 9,000 years, evidenced by findings of remains of chewed agave in different sedimentary floors in caves of the Tehuacan-Cuicatlan Valley $[8,9,10]$. There is also strong archaeological evidence of agave use in Hidalgo State; the oldest lithic records associated with the extraction of sap from agaves are found in the archeological zones of Tula and Tulancingo and are dated at 2,300 years old $[11,12]$.

The ancient and constant interaction between humans and agaves has generated the pressure of different evolutionary forces on the plants, such as artificial selection by several cultural groups that have selected plants with characteristics to satisfy their necessities. This type of selection has exacerbated or reduced the frequency of certain characteristics of the plants, which favor the abundance or reproduction of individuals with these attributes. Plants under the same artificial selective pressures converge on a set of traits that differentiate managed individuals from their ancestors and / or wild relatives; this is known as domestication syndrome $[13,14,15,16]$.

It has been suggested that for the agave species whose main use is the consumption of fresh or fermented beverages, the domestication syndrome is aimed at obtaining a greater quantity and quality of sap, which leads to plants presenting: 1) gigantism -taller overall height and leaf length and width- since larger individuals produce greater volume of sap, 2) the varieties have sap with desirable organoleptic properties like higher sugar content, neutral $\mathrm{pH}$, reduction in irritating compounds and structures such as saponins and raphides, and 3) reduced "spinosity - size, number, and closeness of lateral teeth and size of the terminal spine, all relative to leaf length- to avoid injury to sap collectors from these plant defense mechanisms [16-21]. This means that the terminal spine and lateral teeth are suppressed, smaller or in lesser number in comparison with the wild individuals free of selective pressures, this facilitates the manipulation of the individuals and avoids injuries of the collectors with the plant's mechanisms of defense [16, 19-21].

The morphological variation and domestication syndromes of agaves used for pulque production have been studied by several authors. The results indicate that Agave mapisaga is the largest species and with the smallest lateral teeth, its varieties have only been recorded in anthropic environments, there are no records in natural ecosystems. $A$. salmiana is a species with high morphological diversity, several varied of forms to the exploitation and had a gradient of domestication. On the other hand, $A$. macroculmis and some wild varieties such as $A$. salmiana spp. crassipina, do not show characteristics associated with domestication syndrome [21, 22, 23, 24, 25].

The levels of genetic diversity of the agaves used for pulque production has only been addressed in five studies. The first was by Alfaro-Rojas and collaborators [26], who studied six varieties of cultivated agaves from Mexican highlands using RAPDs as a molecular marker; they found low genetic diversity $(\mathrm{He}=0.038-0.121)$, strong genetic structure $\left(\mathrm{G}_{\mathrm{ST}}=0.68\right)$, and low gene flow $(\mathrm{Nm}=0.24)$. The second study was of the wild relative of the pulque agave, A. salmiana spp. crassipina in San Luis Potosí. In that study, AFLPs were used as the molecular marker, and the authors found high genetic diversity $(\mathrm{He}=0.403)$, no population structure $\left(\mathrm{F}_{\mathrm{ST}}=0\right)$ and gene flow were high (tending toward infinity) [27]. The third and fourth studies were of the $A$. hookeri species in the $P$ 'urhepecha highland in Michoacán, Mexico; nuclear microsatellites showed low population genetic diversity $(\mathrm{He}=0.485)$ compared to the most likely wild ancestor $(A$. inaequidens $\mathrm{He}=0.704-0.733)$, strong population structure $\left(\mathrm{F}_{\mathrm{ST}}=0.28\right)$ and fixation of 
heterozygotes, a genetic trait associated with the selection of favorable genotypes in crops [16, 20]. Finally, ÁlvarezRíos et al. [21], studied five cultivated varieties in Michoacán; they also used nuclear microsatellites and found moderately high genetic diversity values $(\mathrm{He}=0.295-0.583)$ and heterozygote fixation. As has occurred with other agave species used for other purposes such as tequila production, cultivation of a limited number of individuals can produce a founder effect, which leads to a loss of genetic diversity. Similarly, the artificial selection of a unique genotype, especially with vegetative propagation, can also lead to a decrease of diversity and an increase in genetic structure. Another possible scenario is that the artificial selection of certain specific genotypes in the case of the crops come from multiple sources, in addition, the flow of genes via pollen can occur between cultivated genotypes and neighboring population of wild plants $[20,21,28]$.

The state Hidalgo is the federal entity with the largest cultivable area of pulque agave in Mexico. This area of approximately 4,905 ha represents $60 \%$ of the cultivation in the country for the year 2019 , followed by Mexico State with $19 \%$ and Puebla with $12 \%$. Hidalgo is also the top nationwide producer of pulque, with $117,432,130$ liters per year (68\% of the annual national production) [29]. In Hidalgo, as in the rest of the country, the productive systems are made up of several species and subspecies, as well as traditional varieties of agave. However, there is no clear and precise quantification of the proportion of these, nor of their attributes, and there is often not even certainty as to the taxonomic identity of the plants. Agave salmiana var. salmiana and Agave mapisaga are the most widely used species for the extraction of sap, both in extensive crops and within the plots of small producers [21, 22].

Traditional varieties are those useful plants, which are recognized, named, managed, propagated, and preserved by the producers. These varieties are strongly associated with the knowledge of the particular producers, uses and purposes, although their formal taxonomic identity is not sufficiently clear, since some are considered intraspecific categories, or are probably of hybrid origin [21]. In the particular case of agaves, traditional varieties have the following characteristics: 1) they have one or more common names, sometimes in the native language of the locality, referring to obvious characteristics of the plant or to its place of origin, 2) they have been managed by humans over two or more generations, 3) they are used by rural communities for multiple purposes, 4) they can be wild plants managed in situ or cultivated, 5) these varieties are found to a greater extent in traditional production systems, although they can also be found in intensified systems, 6) there is a wealth of traditional knowledge and techniques associated with the management and use of each variety. These traditional varieties are of cultural and economic importance, are part of the identity of cultural groups and satisfy multiple needs, especially the nutritional needs, since the derived products are used both for self-consumption and for commercialization, generating monetary income for the families.

In localities of the Mezquital Valley, Hidalgo, 25 traditional varieties of agaves are reported. Richness is higher in indigenous than mestizo communities, but in both cases, agaves are pillars of food self-sufficiency and family economy $[4,12,22,30,31]$.

Analyzing the characteristics and status of these plant genetic resources is essential to ensure the maintenance of the biological and cultural diversity of Hidalgo and Mexico, as well as to generate information that allows decisionmaking and the design of strategies for sustainable resource management, as well as improving the livelihoods of the communities that maintain, manage, and depend on these resources.

This research was carried out in two localities in the state of Hidalgo with a tradition of using agaves for producing pulque and other purposes. Our objectives were: 1) to carry out an ethnobotanical characterization of the traditional agave varieties and their management categories and describe the productive system, 2) to evaluate the morphological characteristics of the different varieties and to analyze their correspondence with domestication 
syndrome, and 3) to quantify the genetic variability of the different species and traditional varieties of agave. This will allow us to discern the consequences of the management and the degree of domestication of the traditional varieties of agave whose main uses are sap extraction and pulque production in this region of Mexico. We hypothesize that agave varieties with a more intense degree of management will have morphological characteristics associated with the domestication syndrome described for this group of plants for this purpose, while varieties that are less intensely managed will present the characteristics of the syndrome to a lesser extent. On the other hand, we expected cultivated plants to have lower genetic diversity and stronger population structure than wild plants.

\section{Materials And Methods}

Study area. The state of Hidalgo, located in central Mexico, has an area of $20,905 \mathrm{~km}^{2}$, which represents $1.1 \%$ of the total area of Mexico [32] and is divided into 84 municipalities. Four major physiographic features converge within the state: the Mexican Altiplano, the Trans-Mexican Volcanic Belt, the Sierra Madre Oriental and the North-eastern Coastal Altiplano [33]. This leads to a wide diversity of vegetation types. The study was carried out in two localities in Hidalgo (Fig. 1). The first, El Cubo, in the Cardonal municipality of the Mezquital valley is located $11 \mathrm{~km}$ from the Grutas de Tolantongo tourist area. There, we studied the agave plantations of two producers (CCUB1 and CCUB2, Fig. 1A) and measured wild agaves in Cerro Blanco-El Fraile, in the El Sauz locality, located in the same municipality (WSAUZ, Fig. 1B). The second locality was the Rancho La Coyotera, located in the municipality of Zacualtipán de Ángeles within the Barranca de Metztitlán Biosphere Reserve. We studied cultivated agaves in a 40 ha area (CCOY1, Fig. 1C) and wild agave plants found in xeric scrubland of the same locality (WCOY2) (Fig. 1D).

\section{Ethnobotanical Assessment}

We carried out free listings with six agave harvesters, recording the traditional varieties of agaves they recognized and used. Then, we did a semistructured interview to obtain the description of the features of each traditional variety and the management practices associated with each production system. In addition, ethnobotanical walks were conducted with the producers within their plots to recognize the traditional varieties and obtain an in situ record of the practices. Producers often feel more comfortable and confident when immersed in their production systems, leading to a more detailed description of the system's particularities. We used the keys of Gentry [5] for the taxonomic identification of the traditional varieties.

Analysis of morphometric variation of agaves. We selected agaves for morphometric measurements while accompanied by the producers. In total, 111 individuals were measured. We chose "mature" individuals, i.e., plants that would soon develop the floral scape, when producers remove the central meristem to collect the sap. The same selection criteria were used for cultivated and wild agaves. We measured 12 morphological traits in situ. We measured the leaf in the third whorl of the rosette for all leaf measurements. We measured two perpendicular diameters of the plant, then averaged them to obtain a single value. A $15 \mathrm{~cm}$-long section was cut from the middle part of the leaf, preserved in bags with wet paper, then taken to the laboratory to take four measurements associated with the lateral teeth. Leaf color was recorded using the Munsell color system for plant tissues [34]. In addition, we calculated eight relationships between the raw variables, resulting in a total of 25 variables. We carried out multivariate analyses to examine the morphological characteristics of the agave varieties according to the proposed management categories. Statistical analyses were carried out using the R programming language [35]. Due to the different types of characters and units of measurement, we standardized the data matrix using the scale function (mean-centered). We then carried out a Principal Component Analyses (PCA) and constructed a PCA dendrogram 
and heatmap using the complete linkage method. Discriminant Function Analysis (DFA) was performed using JMP software [36].

Sample collection and DNA extraction, amplification, marker screening and data quality. Samples of agave tissue were collected from healthy leaves, dried, and stored on silica gel until DNA extraction [39]. DNA was extracted using the CTAB method [40], purified with chloroform: octanol (24:1) and resuspended in TE buffer. To quantify DNA concentration, 260 and $280 \mathrm{~nm}$ absorbance readings were done on a NanoGenious spectrophotometer (MAPADA Instruments Co., Ltd., 2017). Sixteen nuclear microsatellite loci designed for Agave species were evaluated (Table 1) $[39,40]$. PCR reactions were performed using an ARKTIK thermal cycler (Thermo Scientific), under the following conditions: initial denaturation at $95^{\circ} \mathrm{C}$ for $5 \mathrm{~min}, 30$ denaturation cycles at $95^{\circ} \mathrm{C}$ for $45 \mathrm{~s}$, alignment according to Table 1 for $45 \mathrm{~s}$, and extension at $72{ }^{\circ} \mathrm{C}$ for $40 \mathrm{~s}$, followed by a final incubation at $72{ }^{\circ} \mathrm{C}$ for $5 \mathrm{~min}$. The volume of the reaction mixture was $\sim 8 \mathrm{~L}$ containing $10-50 \mathrm{ng}(1.5 \mu \mathrm{L})$ of genomic $\mathrm{DNA}, 25 \mathrm{mM}(1.6 \mu \mathrm{L})$ of $\mathrm{MgCl}_{2}, 1-10 \mu \mathrm{M}(0.6-$ $1 \mu \mathrm{L})$ of forward and reverse primers, $10 \mathrm{mM}(0.3 \mu \mathrm{L})$ of dNTP mix, $2.3 \mu \mathrm{L}$ of buffer $(5 \mathrm{x}), 0.5 \mu \mathrm{L}$ of DNAse-free water and 1.5U $(0.3 \mu \mathrm{L})$ GoTaq ${ }^{\circledR}$ Flexi DNA Polymerase (Promega). The PCR products were resolved on a $15 \%$ polyacrylamide gel stained with ethidium bromide $(10 \mathrm{mg} / \mathrm{mL})$ run for 90 min at $90 \mathrm{~V}$.

Table 1

Nuclear microsatellites designed for agave species that were amplified in this study. The size ranges, reported base pairs, are provided both from previous reports (see Reference column) and those recovered in this study. The annealing temperature for each locus is shown.

\begin{tabular}{|c|c|c|c|c|}
\hline Locus & $\begin{array}{l}\text { Allele size range } \\
\text { reported (bp) }\end{array}$ & $\begin{array}{l}\text { Allele size range in this } \\
\text { study (bp) }\end{array}$ & $\begin{array}{l}\text { Annealing } \\
\text { temperature }\left({ }^{\circ} \mathrm{C}\right)\end{array}$ & Reference \\
\hline APAR2-12 & $151-205$ & $147-167$ & 63.8 & \multirow{7}{*}{$\begin{array}{l}\text { Lindsay et al } \\
2012\end{array}$} \\
\hline APAR3-11 & $158-194$ & $155-163$ & 63.4 & \\
\hline APARLC20 & $204-240$ & $203-239$ & 59.2 & \\
\hline APARLC21 & $142-206$ & $142-178$ & 56.6 & \\
\hline APARLC28 & $138-195$ & 183-197 & 60 & \\
\hline APARLC34 & $152-206$ & $160-175$ & 64 & \\
\hline APARLC35 & $157-175$ & $158-188$ & 56 & \\
\hline BYU3268 & $138-147$ & $136-145$ & 57.2 & \multirow{9}{*}{$\begin{array}{l}\text { Byers et al. } \\
2014\end{array}$} \\
\hline BYU3674 & $147-156$ & $144-156$ & 59.1 & \\
\hline BYU4012 & $131-140$ & $132-138$ & 60 & \\
\hline BYU4463 & 178-199 & $172-190$ & 60 & \\
\hline BYU4988 & $172-190$ & $167-205$ & 57 & \\
\hline BYU5164 & $155-176$ & $153-181$ & 64 & \\
\hline BYU7269 & $155-167$ & $155-171$ & 64 & \\
\hline BYU8490 & $173-191$ & $163-184$ & 60 & \\
\hline BYU8677 & $171-198$ & $170-192$ & 59 & \\
\hline
\end{tabular}


Alleles (bands) were scored using GelAnalyzer 2010a [41]. We choose the most intense and defined bands to be interpreted as codominant diploid data. After genotyping, the data set was analyzed in Micro-Checker 2.2.3 [42] to determine the presence of null alleles for each locus with 1000 bootstrap simulations and a confidence interval (Cl) with Bonferroni's correction and Chakraborty's estimator [43]. Deviations from Hardy-Weinberg equilibrium (HWE) was tested using the package "pegas" in R $[44,45]$. To check for non-random association among loci, we tested for linkage disequilibrium (LD) in Arlequin ver. 3.5 [46].

Genetic Diversity. The descriptive diversity statistics-the percentage of polymorphic loci (PPL), mean allele diversity $(A)$, effective alleles $(\mathrm{Ae})$, observed and expected heterozygosity $\left(\mathrm{H}_{0}\right.$ and $\left.\mathrm{He}\right)$, and genetic diversity-were calculated using the R package "poppr" $[45,47]$ at the level of traditional varieties and management categories.

Genetic structure. The global and pairwise $\mathrm{F}_{\mathrm{ST}}$ at the level of traditional varieties and management categories were determined using the FreeNA program, which corrects for bias due to the presence of null alleles using the ENA method with 10,000 bootstrap repetitions [48]. The inbreeding coefficient $\left(F_{I S}\right)$ was calculated, correcting for null alleles, with the INEst program [49] using the Bayesian model IIM assuming inbreeding. Each run consisted of 10,000 burn-in and 50,000 periods of Markov Chain Monte Carlo simulations (MCMC). A neighbor-joining tree was constructed based on Nei's genetic distance [50] using $10^{3}$ bootstrap replications in Poptree2 software [51] at the level of traditional varieties. To analyze the genetic structure, we used STRUCTURE v 5.4 under the admixture and correlated allele frequency models [52]. Ten independent runs of 50,000 Markov chain Monte Carlo (MCMC) replications with a burn-in of 50,000 runs for each K-value varying from 1 to 15 groups $(K)$, were performed [53]. The appropriate allocation limit to the number of groups with the lowest accumulated variance was calculated using the graphic method proposed by Evanno et al., [54] generated from the StructureSelector on the web (https://Imme.qdio.ac.cn/StructureSelector/ [55] at the level of traditional varieties. Multivariate statistical approaches using discriminant analysis of principal components (DAPC) were performed and plotted in R using the package "adegenet" at the level of traditional varieties [56].

\section{Results}

Pulque agave production systems and management categories. In El Cubo, the producers have small plots that have been used for producers for at least two generations. The agaves are cultivated in hileras (rows) interspersed with other crops or as living fences within producers' properties. The CCUB1 plot is a production system measuring 3.529 ha, where agaves are cultivated in rows within fields of seasonal crops, such as maize and beans. The CCUB2. 1 plot is a backyard orchard with fruit trees and ornamental plants, occupying an area of 0.35 ha. In the CCUB2.2 and CCUB2.3 plots, agaves are cultivated in rows in within crops, such as maize and beans, and occupy a space of 1.309 and 0.781 ha, respectively, belonging to a single producer of Hñähñu origin. The agaves are propagated by transplanting 50 - to $100 \mathrm{~cm}$-tall suckers from the agaves from the plot into rows. Agaves purchased from other producers in the area are also eventually incorporated into the plots.

Agave suckers are classified for sale according to their vigor into first-rate plants, sold for about 50 Mexican pesos (2 USD) each, and second- and third-rate plants that sell for about 30 Mexican pesos (1.2 USD). Some families in the area sell their plants to pulque producers and barbacoyeros (people who use agave leaves to cook a regional dish: barbacoa de borrego) for 100 Mexican pesos (4 USD) per plant. In this locality we recorded eight traditional varieties of agave used for pulque production. There was one wild variety, known as 1) Corriente, Bronco or Verde de monte, and seven cultivated varieties: 2) Chino, 3) Xaminí, 4) Penca larga, 5) Mutá, 6) Hoc'uadá, 7) Poblano, and 8) Guanté 
(also known as Maguey blanco) (Table 2, Fig. 2). The producers affirm that their ancestors used wild agaves, like Corriente, but they currently only use cultivated agaves. 
Table 2

Characteristics of traditional varieties of agaves identified by producers in the two study localities in Hidalgo state.

Traditional Main Ethnobotany Features
variety
name
( $\mathrm{n}=$
individuals
measured)

\begin{tabular}{|c|c|c|c|c|c|}
\hline $\begin{array}{l}\text { 1. } \\
\text { Corriente, } \\
\text { criollo, de } \\
\text { cerro, } \\
\text { verde. }\end{array}$ & $\begin{array}{l}\text { This is a wild species that is also managed } \\
\text { in some localities. A medium to small plant } \\
\text { with large and abundant lateral teeth. } \\
\text { Produces abundant suckers. The roots are } \\
\text { strong. so some prefer to use it for living }\end{array}$ & W, T, TR & $\begin{array}{l}\text { CCOY1, } \\
\text { WCOY2, } \\
\text { WSAUZ }\end{array}$ & $\begin{array}{l}\text { Agave } \\
\text { salmiana } \\
\text { ssp. } \\
\text { crassispina }\end{array}$ & $\begin{array}{l}\text { CJFU010 } \\
\text { CJFU011 } \\
\text { CJFU015 }\end{array}$ \\
\hline
\end{tabular}

bronco ( $n$ fences, it is extremely easy to transplant.

= 44) Currently it is generally not used for

aguamiel because it produces a low volume per day, produces for fewer days, and sap is

Managed Location Taxonomic Voucher category identity specimen of lower quality (less sweet). It is also used for xanté(agave fiber), although this use is decreasing. It produces a high degree of guixe (contact dermatitis from sap).

\begin{tabular}{|c|c|c|c|c|}
\hline $\begin{array}{l}2 . \\
\text { Corriente- } \\
\text { Cenizo ( } \\
=2)\end{array}$ & $\begin{array}{l}\text { Similar in characteristics to the Corriente } \\
\text { variety, but leaf color is glaucous. }\end{array}$ & W & WCOY2 & $\begin{array}{l}\text { Agave } \\
\text { salmiana } \\
\text { ssp. } \\
\text { crassispina }\end{array}$ \\
\hline
\end{tabular}

\begin{tabular}{|c|c|c|c|c|c|}
\hline $\begin{array}{l}3 . \\
\text { Corriente- } \\
\text { Colorado } \\
(n=1)\end{array}$ & $\begin{array}{l}\text { Similar in characteristics to the Corriente } \\
\text { variety, but it is smaller, with reddish leaves. } \\
\text { Produces very little aguamiel. }\end{array}$ & TR & CCOY1 & $\begin{array}{l}\text { Agave } \\
\text { salmiana } \\
\text { ssp. } \\
\text { crassispina }\end{array}$ & $\begin{array}{l}\text { Photo } \\
\text { record }\end{array}$ \\
\hline $\begin{array}{l}4 . \\
\text { Corriente- } \\
\text { Espina } \\
\text { china ( } n= \\
\text { 1) }\end{array}$ & $\begin{array}{l}\text { This variety is similar to the Corriente variety } \\
\text { but has more pronounced leaf margins } \\
\text { greater size and abundance of lateral teeth. }\end{array}$ & TR & cCOY1 & $\begin{array}{l}\text { Agave } \\
\text { salmiana } \\
\text { var. ferox }\end{array}$ & $\begin{array}{l}\text { Photo } \\
\text { record }\end{array}$ \\
\hline $\begin{array}{l}5 . \\
\text { Corriente- } \\
\text { Penca } \\
\text { ancha ( } n= \\
6)\end{array}$ & $\begin{array}{l}\text { Like Corriente, but was wider, more flexible, } \\
\text { and more fibrous leaves. The leaves of this } \\
\text { variety are used to prepare barbacoa. }\end{array}$ & W & $\begin{array}{l}\text { WCOY2, } \\
\text { WSAUZ }\end{array}$ & $\begin{array}{l}\text { Agave } \\
\text { salmiana } \\
\text { ssp. } \\
\text { crassispina }\end{array}$ & $\begin{array}{l}\text { Photo } \\
\text { record }\end{array}$ \\
\hline $\begin{array}{l}6 . \\
\text { Corriente- } \\
\text { Penca } \\
\text { larga ( } n= \\
7)\end{array}$ & $\begin{array}{l}\text { Remarkably similar to Corriente but has a } \\
\text { longer penca (leaf) and produces sweet } \\
\text { aguamiel. }\end{array}$ & $\mathrm{T}, \mathrm{TR}$ & CCOY1 & $\begin{array}{l}\text { Agave } \\
\text { salmiana }\end{array}$ & $\begin{array}{l}\text { CJFU012 } \\
\text { CJFU013 }\end{array}$ \\
\hline $\begin{array}{l}\text { 7. Manso } \\
\text { de Zoqui o } \\
\text { maguey } \\
\text { fino ( } n= \\
\text { 21) }\end{array}$ & $\begin{array}{l}\text { This variety is purchased in Zoquizoquipan, } \\
\text { Metztitlán municipality. It has been grown } \\
\text { for more than } 40 \text { years in the region. It is the } \\
\text { largest variety and is highly valued because } \\
\text { it produces a large amount of sweeter } \\
\text { aguamiel. It can produce up to four liters a } \\
\text { day for up to five months. }\end{array}$ & C & CCOY1 & $\begin{array}{l}\text { Agave } \\
\text { salmiana } \\
\text { var. } \\
\text { salmiana }\end{array}$ & CJFU014 \\
\hline
\end{tabular}




\begin{tabular}{|c|c|c|c|c|c|}
\hline $\begin{array}{l}\text { Traditional } \\
\text { variety } \\
\text { name } \\
\text { ( } \mathrm{n}= \\
\text { individuals } \\
\text { measured) }\end{array}$ & Main Ethnobotany Features & $\begin{array}{l}\text { Managed } \\
\text { category }\end{array}$ & Location & $\begin{array}{l}\text { Taxonomic } \\
\text { identity }\end{array}$ & $\begin{array}{l}\text { Voucher } \\
\text { specimen }\end{array}$ \\
\hline $\begin{array}{l}\text { 8. Xamini, } \\
\text { Xa 'mni } \\
\text { grande y } \\
\text { chico }(n= \\
\text { 1) }\end{array}$ & $\begin{array}{l}\text { This is a native variety from the Valle del } \\
\text { Mezquital. It is of medium size is } \\
\text { characterized by hook-shaped lateral teeth } \\
\text { (to which the name Xaminí in Hñähñu refers; } \\
\text { can also translated as "spike that scrapes"). } \\
\text { More lateral teeth. Grows fast and is ready } \\
\text { for harvest in } 9 \text { to } 10 \text { years. The sweetest } \\
\text { and least viscous aguamiel called aguamiel } \\
\text { clarito. }\end{array}$ & C & CCUB2.3 & $\begin{array}{l}\text { Agave } \\
\text { salmiana } \\
\text { ssp. } \\
\text { crassispina }\end{array}$ & CJFU007 \\
\hline $\begin{array}{l}\text { 9. Poblano } \\
(\mathrm{n}=13)\end{array}$ & $\begin{array}{l}\text { Arrived in the region } 22 \text { years ago through a } \\
\text { state government program. The plants are } \\
\text { long and have wide leaves (pencas). It is } \\
\text { very susceptible to pests such as pinacatillo } \\
\text { (maguey weevil). Produces a large amount } \\
\text { of aguamiel. }\end{array}$ & $\mathrm{C}$ & CCUB1 & $\begin{array}{l}\text { Agave } \\
\text { salmiana } \\
\text { var. } \\
\text { salmiana }\end{array}$ & CJFU005 \\
\hline $\begin{array}{l}\text { 10. Guanté } \\
\text { o maguey } \\
\text { blanco }(n \\
=3)\end{array}$ & $\begin{array}{l}\text { Cultivated species. Has some morphological } \\
\text { similarities with Xaminí. It takes } 15 \text { years for } \\
\text { the stalk to emerge, which is about two } \\
\text { meters high. }\end{array}$ & $\mathrm{C}$ & $\begin{array}{l}\text { CCUB2.1, } \\
\text { CCUB2.2 }\end{array}$ & $\begin{array}{l}\text { Likely } \\
\text { Agave } \\
\text { americana }\end{array}$ & CJFU008 \\
\hline $\begin{array}{l}\text { 11. Mutha, } \\
\text { Mutá o } \\
\text { penca } \\
\text { ancha }(n= \\
\text { 9) }\end{array}$ & $\begin{array}{l}\text { Has a wide penca (leaf), it is larger than the } \\
\text { Corrientes. Their pencas (leafs) are used for } \\
\text { barbacoa. Takes about } 12 \text { to } 13 \text { years to be } \\
\text { ready to harvest. }\end{array}$ & $\mathrm{C}$ & $\begin{array}{l}\text { CCUB2.1, } \\
\text { CCUB2.2, } \\
\text { CCUB2.3 }\end{array}$ & $\begin{array}{l}\text { Agave } \\
\text { salmiana } \\
\text { var. } \\
\text { salmiana }\end{array}$ & CJFU006 \\
\hline $\begin{array}{l}\text { 12. Penca } \\
\text { larga }(n= \\
\text { 4) }\end{array}$ & $\begin{array}{l}\text { It is a large variety, with long leaves and } \\
\text { slightly rigid, takes about } 14 \text { years to be } \\
\text { ready for harvest. Aguamiel is more viscous } \\
\text { than other varieties. It used to take ayate } \\
\text { (fiber). This is not good for barbacoa. Does } \\
\text { produce aguamiel, but it is more viscous, so } \\
\text { pulque from this variety is thicker and spoils } \\
\text { quickly. }\end{array}$ & $\mathrm{C}$ & $\begin{array}{l}\text { CCUB2.1, } \\
\text { CCUB2.2, } \\
\text { CCUB2.3 }\end{array}$ & $\begin{array}{l}\text { Agave } \\
\text { mapisaga }\end{array}$ & CJFU002 \\
\hline
\end{tabular}

In this locality, each producer uses six to 20 plants simultaneously. The sap is collected with the elongated tool known as an acocote, essentially a large straw. One end is inserted into the cavity of the agave, and suction is generated by mouth at the other end, drawing the sap into the acocote which is then emptied into a bucket. Acocotes were traditionally made with a long, dried calabash fruit (Lagenaria siceraria), however due to the low availability of this material and its fragility, it has been replaced by plastic materials. Currently, acocotes are made by attaching a plastic hose (the end inserted into the plant) to a plastic bottle, which is drilled at the base (to allow suction). Pulque is produced with a combination of different sap varieties. The producers mix the fresh sap with old pulque, produced the day before. The fresh sap and pulque are used for self-consumption and sold locally at 10 Mexican pesos ( 0.4 USD) per liter, or to tourists for 25 Mexican Pesos (1 USD) per liter.

La Coyotera has been cultivating agaves for around 30 years. A total of 44 hectares are dedicated to agave production, where the plants are found at different densities and are managed in three ways: living fences, jilas, and nursery. For living fences, used to delimit spaces and paths, the wild Corriente variety is preferred, since it has more teeth, longer spines, is fast growing, and has deep roots. Jilas refers to rows of agaves that are interspersed with 
native vegetation and are planted perpendicular to the slope of the land. Juvenile agaves are cultivated and kept in nurseries to protect them from goat browsing and allow them to develop and are then transplanted into the jilas when they reach $100 \mathrm{~cm}$ in height.

The cultivated agaves come from various sources, including from the suckers of wild agaves from nearby areas and suckers bought from local producers and from other productive areas such as Zoquizoquiapan, Zotoltepec and Singuilucan in Hidalgo and Magdalena Contreras in Mexico City. In this locality, wild agaves are also used to produce pulque. Fourteen traditional varieties used for pulque production were listed: 1) Corriente, 2) CorrienteCenizo, 3) Corriente-Colorado, 4) Corriente-Espina china 5) Corriente-Penca ancha, 6) Corriente-Penca larga, 7) Manso de Zoqui, 8) Manso del Altiplano, 9) Xaminí, 10) Púa larga, 11) Verde, 12) Penca larga 13) Blanco and 14) Sabililla (Table 2, Fig. 2). In this locality, 35 plants are used simultaneously, collecting, and preparing pulque similarly to the other locality and the price per liter is 10 Mexican pesos (0.4 USD).

In both localities there is a gradient of management practices that can be grouped into the following categories:

1) Wild (W). Agaves that inhabit the surrounding areas of native vegetation. These plants can eventually be collected and used for various purposes. According to the people interviewed, some 70 years ago there were no crops, and these agaves were used.

2) Tolerated (T). Agaves of wild origin, which in the conversion of an area with native vegetation to a productive system, have been maintained by the managers within the new system. These plants receive some management, such as removing dry leaves.

3) Transplanted (TR). Agaves removed from their original place, generally from nearby ecosystems, and placed within productive systems, forming part of the rows, and living fences.

4) Cultivated (C): Agaves cultivated within productive systems. This category generally contains the most used and valued traditional varieties. These are given greater care, including pruning and more intense propagation. These are the varieties that are bought or exchanged between localities.

Producers identify qualitative characteristics that make it possible to distinguish cerro and monte agaves (wild) from cultivated ones. These characteristics are the size of the plant and its leaves, the shape and length of the spines, and the number of lateral teeth. Another important characteristic for handlers is the color of the plant, which ranges from different shades of green to glaucous. Characteristics such as the time to reproductive maturity, the sap quantity, and qualities (such as sweetness or viscosity), and the duration of sap production are also considered (Table 2). Wild agaves can be distinguished from cultivated agaves because they are not aligned, have a smaller rosette with many lateral teeth, and are larger than cultivated ones. Of the traditional varieties described in Table 2, three were found in natural ecosystems and correspond to wild (W), two are tolerated within production systems (T), four varieties were transplanted from native vegetation to managed areas (TR) and six varieties are cultivated (C). The traditional variety Corriente is the most abundant and can be found in the most of management categories.

Morphological variability of pulque agaves. Of the 19 traditional varieties recorded, it was only possible to morphologically characterize 12 varieties because no measurable individuals were found in production of the other seven. Based on 23 morphometric variables, the first two PCA components together explained $47 \%$ of the variance (PC1: 29\%, PC2: 18\%; Fig. 3). The ordering of PC1 was related to the size of the plant, and the most important variables were leaf length (LL), General plant length (GPL), stem length (SL), the ratio of the length of lateral teeth to the length of the blade (LTEE / LL), and diameter (D). In PC2, the most important variables were associated with the 
plant's thorniness: the ratio of the distance between teeth and the length of the leaf (DTEE / LL), the length of the lateral teeth (LTEE), number of teeth per $10 \mathrm{~cm}$ (TEE10), the length of the terminal spine (TTL), and the distance between teeth (DTEE) (Table 3). The agaves of the different varieties sorted by management category, with wild agaves found on the extreme left of the arrangement and cultivated in the right, while the transplanted and tolerated individuals are located in the center (Fig. 3A). 
Table 3

Vegetative morphological characteristics measured in the traditional varieties of agaves recorded in the localities Rancho La Coyotera and El Cubo studied in the state of Hidalgo. The columns show eigenvectors of the first (PC1) and second (PC2) principal components according to PCA and eigenvectors of the first (DF1) and second (DF2) factors of the DFA. Bold letters indicate the characteristic with greatest contribution to ordination.

\begin{tabular}{|c|c|c|c|c|}
\hline Vegetative character & PC1 & PC2 & DF1 & DF2 \\
\hline General plant lenght (GPL) & 0.350 & 0.055 & 0.302 & 0.339 \\
\hline Stem lenght (SL) & 0.308 & -0.027 & 0.016 & 0.096 \\
\hline $\begin{array}{l}\text { Mean diameter of the plant } \\
\text { (D) }\end{array}$ & 0.274 & -0.005 & -0.135 & 0.165 \\
\hline Leaf lenght (LL) & 0.355 & 0.061 & 1.492 & 0.598 \\
\hline Leaf number (LN) & 0.057 & -0.125 & -0.425 & -0.303 \\
\hline Thickness leaf (TS) & -0.020 & 0.216 & -0.290 & -0.295 \\
\hline Suckers (S) & $\begin{array}{l}\text { not included in } \\
\text { the analysis }\end{array}$ & $\begin{array}{l}\text { not included in } \\
\text { the analysis }\end{array}$ & -0.127 & -0.220 \\
\hline Leaf width at middle (LW) & 0.186 & -0.219 & 0.416 & -0.039 \\
\hline Leaf width at base (LB) & 0.266 & -0.037 & 0.160 & 0.338 \\
\hline LL/LW & 0.179 & 0.264 & 1.054 & 0.131 \\
\hline LL/SL & -0.143 & 0.078 & -0.721 & 0.768 \\
\hline Terminal thorn length (TTL) & 0.078 & -0.303 & -0.054 & 0.038 \\
\hline $\begin{array}{l}\text { Terminal thorn width at the } \\
\text { base (TTW) }\end{array}$ & 0.235 & 0.013 & 0.554 & -0.349 \\
\hline $\begin{array}{l}\text { Terminal thorn distance a first } \\
\text { tooth (TTL-TEE) }\end{array}$ & $\begin{array}{l}\text { not included in } \\
\text { the analysis }\end{array}$ & $\begin{array}{l}\text { not included in } \\
\text { the analysis }\end{array}$ & $\begin{array}{l}\text { not included in } \\
\text { the analysis }\end{array}$ & $\begin{array}{l}\text { not included in } \\
\text { the analysis }\end{array}$ \\
\hline TTL/TTW & -0.155 & -0.182 & 0.406 & 0.109 \\
\hline TTL/LL & -0.132 & -0.120 & -0.368 & 0.053 \\
\hline Total number of teeth (TEET) & 0.183 & 0.262 & -0.583 & -0.070 \\
\hline TEET/LL & -0.184 & 0.227 & 0.454 & -0.076 \\
\hline $\begin{array}{l}\text { Number of teeth in } 10 \mathrm{~cm}^{2} \\
\text { (TEE10) }\end{array}$ & -0.198 & 0.311 & 0.167 & -0.138 \\
\hline Teeth length (LTEE) & -0.154 & -0.312 & -0.118 & -1.805 \\
\hline LTEE/LL & -0.280 & -0.214 & 0.678 & 2.174 \\
\hline Teeth width (WTEE) & 0.131 & -0.264 & -0.402 & -0.186 \\
\hline LTEE/WTEE & -0.211 & -0.184 & -0.560 & 0.761 \\
\hline $\begin{array}{l}\text { Distance between teeth } \\
\text { (DTEE) }\end{array}$ & 0.205 & -0.299 & 0.956 & 0.835 \\
\hline DTEE/LL & 0.072 & -0.337 & -0.150 & -0.241 \\
\hline
\end{tabular}




\begin{tabular}{|lllll|}
\hline Vegetative character & PC1 & PC2 & DF1 & DF2 \\
\hline Color (C) & $\begin{array}{l}\text { not included in } \\
\text { the analysis }\end{array}$ & $\begin{array}{l}\text { not included in } \\
\text { the analysis }\end{array}$ & $\begin{array}{l}\text { not included in } \\
\text { the analysis }\end{array}$ & $\begin{array}{l}\text { not included in } \\
\text { the analysis }\end{array}$ \\
\hline
\end{tabular}

The heatmap showed that the agaves were grouped according to the management category. The cultivated agaves had larger size and were less thorny, regardless of their variety. They had smaller lateral teeth and a teeth in a smaller proportion with respect to the leaf. Wild individuals were grouped in the middle part of the heatmap, with smaller size than agaves of the other categories, but increased thorniness. The bottom of the heatmap had a mixture of individuals from all categories, especially the agaves of the tolerated and transplanted categories, which had intermediate characteristics between the other extremes of the management classification (Fig. 3B).

Regarding the characteristics associated with gigantism, the wild variety Corriente ( $A$. salmiana ssp. crassispina) was the smallest in terms of GPL, SL, D, and LL. The cultivated variety Penca larga (A. mapisaga) was the largest in terms of GPL, D and LL, while the cultivated variety Poblano ( $A$. salmiana var. salmiana) had the highest average SL. In terms of thorniness, Penca larga had more teeth and more closely spaced teeth than the other varieties, but the size of the teeth was smaller than the wild varieties. The variety Manso de Zoqui also had a smaller tooth size. This confirms the domestication syndrome of lesser dentition for easier manipulation (Table 4). Carrying out the morphological comparisons among the management categories, we found that the wild category was the smallest (GPL, SL, D, LL) and cultivated the largest. Wild agaves had larger lateral tooth sizes, but not a larger Terminal thorn (TTL), which was similar among all management categories (Table 5). 
Table 4

Vegetative morphological characteristics of eight traditional varieties of pulque agave, identified by producers in the localities of La Coyotera and El Cubo, in the state of Hidalgo.

\begin{tabular}{|c|c|c|c|c|c|c|c|c|}
\hline \multirow{2}{*}{$\begin{array}{l}\text { Vegetative } \\
\text { character }\end{array}$} & \multicolumn{8}{|c|}{ Traditional varieties of agave } \\
\hline & Corriente & $\begin{array}{l}\text { Corriente- } \\
\text { Penca } \\
\text { ancha }\end{array}$ & $\begin{array}{l}\text { Corriente- } \\
\text { Penca } \\
\text { Larga }\end{array}$ & $\begin{array}{l}\text { Manso } \\
\text { de } \\
\text { Zoqui }\end{array}$ & Poblano & Guanté & Mutá & $\begin{array}{l}\text { Penca } \\
\text { larga }\end{array}$ \\
\hline $\begin{array}{l}\text { General plant } \\
\text { length (GPL) }\end{array}$ & $\begin{array}{l}172.955 \\
\pm 4.185\end{array}$ & $\begin{array}{l}194.000 \\
\pm 7.625\end{array}$ & $\begin{array}{l}218.714 \\
\pm 6.578\end{array}$ & $\begin{array}{l}256.286 \\
\pm 8.050\end{array}$ & $\begin{array}{l}252.308 \\
\pm 8.209\end{array}$ & $\begin{array}{l}225.333 \\
\pm 6.227\end{array}$ & $\begin{array}{l}240.333 \\
\pm 10.813\end{array}$ & $\begin{array}{l}260.000 \\
\pm 10.206\end{array}$ \\
\hline $\begin{array}{l}\text { Stem length } \\
\text { (SL) }\end{array}$ & $\begin{array}{l}42.898 \\
\pm 2.520\end{array}$ & $\begin{array}{l}50.000 \pm \\
5.882\end{array}$ & $\begin{array}{l}80.243 \pm \\
5.096\end{array}$ & $\begin{array}{l}68.829 \\
\pm 3.233\end{array}$ & $\begin{array}{l}81.692 \\
\pm 4.532\end{array}$ & $\begin{array}{l}71.667 \\
\pm \\
3.333 \mathrm{~g}\end{array}$ & $\begin{array}{l}78.444 \\
\pm 3.271\end{array}$ & $\begin{array}{l}66.750 \\
\pm 3.728\end{array}$ \\
\hline $\begin{array}{l}\text { Mean } \\
\text { diameter of } \\
\text { the plant (D) }\end{array}$ & $\begin{array}{l}253.523 \\
\pm 6.498\end{array}$ & $\begin{array}{l}271.417 \\
\pm 13.679\end{array}$ & $\begin{array}{l}303.000 \\
\pm 10.341\end{array}$ & $\begin{array}{l}321.024 \\
\pm 9.249\end{array}$ & $\begin{array}{l}368.692 \\
\pm 14.644\end{array}$ & $\begin{array}{l}331.500 \\
\pm 4.770\end{array}$ & $\begin{array}{l}296.944 \\
\pm 45.123\end{array}$ & $\begin{array}{l}369.500 \\
\pm 8.663\end{array}$ \\
\hline $\begin{array}{l}\text { Leaf length } \\
\text { (LL) }\end{array}$ & $\begin{array}{l}116.561 \\
\pm 2.801\end{array}$ & $\begin{array}{l}132.167 \\
\pm 5.089\end{array}$ & $\begin{array}{l}143.857 \\
\pm 4.748\end{array}$ & $\begin{array}{l}188.438 \\
\pm 6.138\end{array}$ & $\begin{array}{l}185.154 \\
\pm 6.052\end{array}$ & $\begin{array}{l}148.000 \\
\pm 2.000\end{array}$ & $\begin{array}{l}180.000 \\
\pm 5.336\end{array}$ & $\begin{array}{l}209.750 \\
\pm 11.213\end{array}$ \\
\hline $\begin{array}{l}\text { Terminal } \\
\text { thorn length } \\
\text { (TTL) }\end{array}$ & $\begin{array}{l}5.051 \pm \\
0.165\end{array}$ & $\begin{array}{l}5.554 \pm \\
0.319\end{array}$ & $\begin{array}{l}4.138 \pm \\
0.611\end{array}$ & $\begin{array}{l}5.408 \pm \\
0.224\end{array}$ & $\begin{array}{l}6.069 \pm \\
0.339\end{array}$ & $\begin{array}{l}3.713 \pm \\
1.408\end{array}$ & $\begin{array}{l}6.479 \pm \\
0.462\end{array}$ & $\begin{array}{l}3.225 \pm \\
0.183\end{array}$ \\
\hline $\begin{array}{l}\text { Number of } \\
\text { teeth in } \\
10 \mathrm{~cm}^{2} \\
\text { (TEE10) }\end{array}$ & $\begin{array}{l}3.636 \pm \\
0.187\end{array}$ & $\begin{array}{l}2.667 \pm \\
0.333\end{array}$ & $\begin{array}{l}3.143 \pm \\
0.340\end{array}$ & $\begin{array}{l}2.429 \pm \\
0.177\end{array}$ & $\begin{array}{l}2.000 \pm \\
0.000\end{array}$ & $\begin{array}{l}2.000 \pm \\
0.000\end{array}$ & $\begin{array}{l}2.000 \pm \\
0.167\end{array}$ & $\begin{array}{l}4.750 \pm \\
0.629\end{array}$ \\
\hline $\begin{array}{l}\text { Teeth length } \\
\text { (LTEE) }\end{array}$ & $\begin{array}{l}0.769 \pm \\
0.043\end{array}$ & $\begin{array}{l}0.750 \pm \\
0.042\end{array}$ & $\begin{array}{l}0.716 \pm \\
0.057\end{array}$ & $\begin{array}{l}0.469 \pm \\
0.027\end{array}$ & $\begin{array}{l}0.794 \pm \\
0.060\end{array}$ & $\begin{array}{l}0.699 \pm \\
0.121\end{array}$ & $\begin{array}{l}0.768 \pm \\
0.066\end{array}$ & $\begin{array}{l}0.301 \pm \\
0.029\end{array}$ \\
\hline LTEE/LL & $\begin{array}{l}0.007 \pm \\
0.000\end{array}$ & $\begin{array}{l}0.006 \pm \\
0.000\end{array}$ & $\begin{array}{l}0.005 \pm \\
0.000\end{array}$ & $\begin{array}{l}0.003 \pm \\
0.000\end{array}$ & $\begin{array}{l}0.004 \pm \\
0.000\end{array}$ & $\begin{array}{l}0.005 \pm \\
0.001\end{array}$ & $\begin{array}{l}0.004 \pm \\
0.000\end{array}$ & $\begin{array}{l}0.001 \pm \\
0.000\end{array}$ \\
\hline $\begin{array}{l}\text { Distance } \\
\text { between teeth } \\
\text { (DTEE) }\end{array}$ & $\begin{array}{l}1.687 \pm \\
0.015\end{array}$ & $\begin{array}{l}2.595 \pm \\
0.597\end{array}$ & $\begin{array}{l}2.020 \pm \\
0.304\end{array}$ & $\begin{array}{l}3.058 \pm \\
0.254\end{array}$ & $\begin{array}{l}4.509 \pm \\
0.277\end{array}$ & $\begin{array}{l}4.389 \pm \\
0.618\end{array}$ & $\begin{array}{l}4.892 \pm \\
0.698\end{array}$ & $\begin{array}{l}0.778 \pm \\
0.066\end{array}$ \\
\hline DTEE/LL & $\begin{array}{l}0.015 \pm \\
0.0\end{array}$ & $\begin{array}{l}0.020 \pm \\
0.0\end{array}$ & $\begin{array}{l}0.014 \pm \\
0.0\end{array}$ & $\begin{array}{l}0.017 \pm \\
0.0\end{array}$ & $\begin{array}{l}0.025 \pm \\
0.002\end{array}$ & $\begin{array}{l}0.030 \pm \\
0.004\end{array}$ & $\begin{array}{l}0.028 \pm \\
0.004\end{array}$ & $\begin{array}{l}0.004 \pm \\
0.001\end{array}$ \\
\hline $\begin{array}{l}\text { Allele richness } \\
\text { (A) }\end{array}$ & $\begin{array}{l}6.000 \pm \\
0.428\end{array}$ & $\begin{array}{l}3.313 \pm \\
0.285\end{array}$ & $\begin{array}{l}2.813 \pm \\
0.306\end{array}$ & $\begin{array}{l}3.500 \pm \\
0.316\end{array}$ & $\begin{array}{l}3.313 \pm \\
0.435\end{array}$ & $\begin{array}{l}1.563 \pm \\
0.182\end{array}$ & $\begin{array}{l}3.063 \pm \\
0.452\end{array}$ & $\begin{array}{l}2.313 \pm \\
0.237\end{array}$ \\
\hline $\begin{array}{l}\text { Allele } \\
\text { effective (Ae) }\end{array}$ & $\begin{array}{l}4.073 \pm \\
0.303\end{array}$ & $\begin{array}{l}2.590 \pm \\
0.221\end{array}$ & $\begin{array}{l}2.226 \pm \\
0.238\end{array}$ & $\begin{array}{l}2.390 \pm \\
0.235\end{array}$ & $\begin{array}{l}2.495 \pm \\
0.345\end{array}$ & $\begin{array}{l}1.459 \pm \\
0.146\end{array}$ & $\begin{array}{l}2.294 \pm \\
0.347\end{array}$ & $\begin{array}{l}1.975 \pm \\
0.193\end{array}$ \\
\hline $\begin{array}{l}\text { Observed } \\
\text { Heterocigozity } \\
\text { (Ho) }\end{array}$ & $\begin{array}{l}0.190 \pm \\
0.052\end{array}$ & $\begin{array}{l}0.167 \pm \\
0.050\end{array}$ & $\begin{array}{l}0.161 \pm \\
0.070\end{array}$ & $\begin{array}{l}0.143 \pm \\
0.056\end{array}$ & $\begin{array}{l}0.214 \pm \\
0.086\end{array}$ & $\begin{array}{l}0.146 \pm \\
0.074\end{array}$ & $\begin{array}{l}0.203 \pm \\
0.083\end{array}$ & $\begin{array}{l}0.125 \pm \\
0.065\end{array}$ \\
\hline $\begin{array}{l}\text { Expected } \\
\text { Heterocigozity } \\
(\mathrm{He})\end{array}$ & $\begin{array}{l}0.730 \pm \\
0.023\end{array}$ & $\begin{array}{l}0.562 \pm \\
0.046\end{array}$ & $\begin{array}{l}0.493 \pm \\
0.040\end{array}$ & $\begin{array}{l}0.517 \pm \\
0.048\end{array}$ & $\begin{array}{l}0.487 \pm \\
0.059\end{array}$ & $\begin{array}{l}0.219 \pm \\
0.065\end{array}$ & $\begin{array}{l}0.435 \pm \\
0.066\end{array}$ & $\begin{array}{l}0.410 \pm \\
0.061\end{array}$ \\
\hline $\begin{array}{l}\text { Inbreeding } \\
\text { coefficient } \\
\left(\mathrm{F}_{\mathrm{IS}}\right)(\mathrm{CI})\end{array}$ & $\begin{array}{l}0.716 \\
(0.680- \\
0.719)\end{array}$ & $\begin{array}{l}0.702 \\
(0.565- \\
0.709)\end{array}$ & $\begin{array}{l}0.562 \\
(0.378- \\
0.575)\end{array}$ & $\begin{array}{l}0.643 \\
(0.523- \\
0.647)\end{array}$ & $\begin{array}{l}0.159 \\
(0.150- \\
0.275)\end{array}$ & $\begin{array}{l}0.194 \\
(0.003- \\
0.228)\end{array}$ & $\begin{array}{l}0.324 \\
(0.077- \\
0.326)\end{array}$ & $\begin{array}{l}0.650 \\
(0.353- \\
0.656)\end{array}$ \\
\hline
\end{tabular}


Table 5

Vegetative morphological characteristics according to the management categories of the eight traditional varieties of pulque agaves, identified by producers in the localities of La Coyotera and El Cubo, in the state of Hidalgo.

\begin{tabular}{|c|c|c|c|c|}
\hline \multirow[t]{2}{*}{ Vegetative character } & \multicolumn{4}{|c|}{ Management category } \\
\hline & Wild (W) & Tolerated $(\mathrm{T})$ & $\begin{array}{l}\text { Transplanted } \\
\text { (TR) }\end{array}$ & Cultivated (C) \\
\hline General plant length (GPL) & $\begin{array}{l}170.850 \pm \\
5.085\end{array}$ & $202.455 \pm 9.646$ & $207.875 \pm 11.311$ & $\begin{array}{l}246.615 \pm \\
4.436\end{array}$ \\
\hline Stem length (SL) & $40.025 \pm 2.459$ & $64.909 \pm 4.689$ & $68.963 \pm 5.498$ & $73.460 \pm 2.156$ \\
\hline Mean diameter of the plant (D) & $\begin{array}{l}249.900 \pm \\
9.275\end{array}$ & $\begin{array}{l}289.091 \pm \\
17.687\end{array}$ & $294.938 \pm 20.720$ & $\begin{array}{l}328.603 \pm \\
8.135\end{array}$ \\
\hline Leaf length (LL) & $\begin{array}{l}115.200 \pm \\
3.792\end{array}$ & $135.273 \pm 7.232$ & $142.500 \pm 8.480$ & $\begin{array}{l}181.998 \pm \\
3.326\end{array}$ \\
\hline Terminal thorn length (TTL) & $5.049 \pm 0.210$ & $4.777 \pm 0.400$ & $4.473 \pm 0.469$ & $5.479 \pm 0.184$ \\
\hline $\begin{array}{l}\text { Number of teeth in } 10 \mathrm{~cm}^{2} \\
\text { (TEE10) }\end{array}$ & $3.450 \pm 0.178$ & $3.091 \pm 0.339$ & $3.750 \pm 0.398$ & $2.500 \pm 0.156$ \\
\hline Teeth length (LTEE) & $0.800 \pm 0.041$ & $0.713 \pm 0.077$ & $0.660 \pm 0.091$ & $0.622 \pm 0.036$ \\
\hline LTEE/LL & $0.007 \pm 0.000$ & $0.005 \pm 0.001$ & $0.005 \pm 0.00$ & $0.004 \pm 0.000$ \\
\hline Distance between teeth (DTEE) & $1.851 \pm 0.216$ & $2.099 \pm 0.411$ & $1.567 \pm 0.482$ & $3.556 \pm 0.189$ \\
\hline DTEE/LL & $0.016 \pm 0.001$ & $0.015 \pm 0.003$ & $0.012 \pm 0.003$ & $0.020 \pm 0.001$ \\
\hline Allele richness (A) & $5.587 \pm 0.407$ & $2.250 \pm 0.348$ & $3.063 \pm 0.347$ & $5.188 \pm 0.572$ \\
\hline Allele effective (Ae) & $3.562 \pm 0.221$ & $2.386 \pm 0.281$ & $2.389 \pm 0.255$ & $3.418 \pm 0.572$ \\
\hline Observed Heterocigozity $\left(\mathrm{H}_{\mathrm{O}}\right)$ & $0.187 \pm 0.048$ & $0.204 \pm 0.079$ & $0.135 \pm 0.064$ & $0.167 \pm 0.058$ \\
\hline Expected Heterocigozity (He) & $0.701 \pm 0.020$ & $0.495 \pm 0.055$ & $0.504 \pm 0.053$ & $0.646 \pm 0.040$ \\
\hline
\end{tabular}

The DFA explained $96.03 \%$ of the variance (DF1 83.46\%; DF2 12.58\%). Three large groups were differentiated; one contained the wild traditional varieties (at the left in Fig. 3C), a second was composed of cultivated traditional varieties (at the right in Fig. $3 \mathrm{C}$ ), and a third group contained the tolerated and transplanted traditional varieties (center bottom). The variables with the highest eigenvalues in DF1 were LL, LL/LW, LL/SL, TTW, TEET, LTEE/LL, LTEE/WTEE and DTEE. In the case of DF2, they were LL, LL/SL, LTEE, LTEE/WLEE, and DTEE. These characteristics are associated with the length of the leaves and the dentition. The first group, in the upper left it is made up of wild individuals of the traditional varieties Corriente, Corriente-Cenizo and Corrriente-Penca ancha. The second group (top right) is made up of individuals cultivated from traditional varieties Penca larga, Manso de Zoqui, Mutá and Poblano. The third group (bottom center) corresponds to tolerated and transplanted individuals of different varieties (their centroids did not differ), even wild and cultivated individuals are distinguished. The Wilk's Lambda had a value close to zero $(0.05 ; p<0.001)$, indicating that the information provided by the variable is statistically significant, allowing the discrimination of groups whose centroids are not same (Wild and cultivated) and have little overlap. Only $7 \%$ of the individuals were not correctly classified into the category management assigned a priori. $90 \%$ of the individuals in the management category W were classified correctly; $7.5 \%$ were classified T and $2.5 \%$ to TR. $85 \%$ of 
the individuals in the T category were classified correctly and 15\% classified as TR. All individuals in the TR category

were correctly classified. In the case of management category C, $96 \%$ were classified correctly and $4 \%$ to category T.

\section{Genetic diversity and structure}

Null alleles were found at 16 loci, suggesting homozygote excess. Only one locus (BYU4463) did not exhibit null alleles. The estimated null allele frequencies over traditional varieties and managed category varied from -0.0738 (7\%) at BYU4463 (this suggest heterozygote excess) to 1 (monomorphic loci) at APAR3-11, APARLC28, APARLC34 and BYU 4012. Sixteen loci showed departures from HWE $(p<0.05)$. LD was observed between four pairs of loci $(p<$ 0.05: APAR2-12 x APAR3-11, APARLC-21 x APARLC-28, APARLC-34 x BYU3674 and APARLC-35 x BYU4012. The percentage of polymorphic loci (PPL) in traditional varieties ranged from 43.75\% (Guantê) to 100\% (Corriente, Corriente-Penca Larga and Manso de Zoqui). In the managed categories, this was $100 \%$ for wild (W) and cultivated (C) and $93.75 \%$ for tolerated $(T)$ and transplanted (TR). The allele richness (A) in the traditional varieties ranged from 1.563 (Guante) to 6 (Corriente), and the effective number of alleles (Ae) varied from 1.459 to 4.076 in the same traditional varieties (Guanté and Corriente respectively; Table 4). In the managed categories, the allele richness ranged from $3.063(\mathrm{TR})$ to $5.875(\mathrm{~W})$, and the effective number of alleles (Ae) was 2.386 to 3.562 in the same managed categories (TR, T and W, Table 5). The observed heterozygosity $(\mathrm{Ho})$ in traditional varieties ranged from 0.125 (Penca larga) to 0.214 (Poblano) and the expected heterozygosity (He) varied from 0.219 (Guante) to 0.730 (Corriente) (Table 4). In managed categories, the observed heterozygosity $\left(\mathrm{H}_{0}\right)$ ranged from $0.135(\mathrm{TR})$ to $0.204(\mathrm{~T})$ and the expected heterozygosity $(\mathrm{He})$ varied from $0.495(\mathrm{~T})$ to 0.701 (W, Table 5). Average levels of genetic variation at species level for Agave salmiana was $(\mathrm{Hs}=0.564, \mathrm{~N}=7)$, for $A$. salmiana ssp. crassispina $(\mathrm{Hs}=0.738 ; \mathrm{N}=73)$, for Agave salmiana var. salmiana $(\mathrm{Hs}=0.540, \mathrm{~N}=21)$; for $A$. mapisaga $(\mathrm{Hs}=0.526, \mathrm{~N}=4)$ and for $A$. americana $\left(\mathrm{H}_{\mathrm{S}}=\right.$ $0.291, \mathrm{~N}=3$ ). $\mathrm{F}_{\mathrm{ST}}$ with ENA correction was 0.127 , indicating a moderate genetic differentiation between managed categories. $\mathrm{F}_{\mathrm{IS}}$ ranged from 0.194 (Guante) to 0.720 (Corriente), indicating strong endogamy. The neighbor joining tree based on Nei's distances showed three groups. The first included the traditional varieties: Corriente, CorrienteCenizo and Corriente-Penca ancha, the second group was formed by the Corriente-Colorado, Corriente-Espina china, Corriente-Penca larga and Manso de Zoqui varieties, and the third contained the Poblano, Mutá, Guanté, Penca Larga and Xaminívarieties (Fig. 4A). The Bayesian cluster analysis indicated that the most likely number of genetics group was three ( $K=3$, Fig. 4B). The blue genetic group corresponds to the category of wild management and the traditional varieties Corriente, Corriente-Cenizo and Corriente-Penca ancha. The orange group is made up of individuals that are tolerated, transplanted, and cultivated, with the traditional varieties Corriente, Corriente penca larga, Corriente-Colorado, Corriente-Espina China, and Manso de Zoqui. The purple group corresponds to the category of cultivated management and the traditional varieties Xaminí, Poblano, Guanté, Mutá and Penca larga. This analysis corresponds to the grouping of the dendrogram. The DAPC also grouped the plants according to the management categories, in the upper part in the center the wild traditional varieties (Fig. 4C) matched the dendrogram and Bayesian clustering. In the lower left, the cultivated traditional varieties (Poblano, Guanté, Mutá, Corriente-Penca Larga and Xamini) and in the lower right a mixed group between the tolerated and transplanted traditional varieties together with a cultivated traditional variety Manso de Zoqui.

\section{Discussion}

A rich diversity of traditional varieties of pulque agave are used in the localities studied in the state of Hidalgo, which are maintained in a management gradient in traditional agroforestry systems. The crop plants clearly exhibited domestication syndrome related to gigantism and reduced spinosity. We also found support for the hypothesis of

Page $17 / 30$ 
decreased genetic diversity and moderate population structure among cultivated pulque agaves compared to wild plants.

Agrobiodiversity of pulque agave in the State of Hidalgo. In Mexico, about 117 agave taxa have been reported to be used, which have been assigned about 570 common names and represent varieties of agronomic interest [57]. We found a high diversity of traditional varieties of pulque agave, which are compared with those recorded by other authors in other regions of the country. Although there is a wide agrobiodiversity of pulque agaves, they are taxonomically reduced to three species: Agave americana, A. salmiana and A. mapisaga. The assignment of taxonomic identities in agaves is a complex task. Some of the species descriptions are based on ex situ specimens, and agaves are a group of plants where hybridization is a common process, even more so in cultivated species and varieties. In our case, the plants managed in crops are difficult to identify at the species level because reproductive structures are frequently removed as part of management, so these structures are not available to aid in identification.

In the southern highlands, Mora-López et al. [22] recorded 62 varieties of pulque agaves. On the other hand, for the state of Hidalgo, Reyes-Agüero et al. [31] found that the mestizo and Hñahñü communities of the Mezquital Valley manage around 15 and 21 varieties, respectively. In our case, we recorded similar numbers of varieties with the same trends as Reyes-Agüero et al. [31], since the production system managed by the oldest producer of Hñahñü origin maintains unusual traditional varieties that were not recorded in other production systems. In the state of Puebla, Álvarez-Duarte et al. [24] recorded seven varieties of pulque agaves and, unlike previous studies, producers in this area maintain the species $A$. applanata among their crops, which was widely used in the past. In the state of Tlaxcala, nine varieties of pulque agaves have recently been identified, with the novelty that the Ayoteco variety, which had been located taxonomically as $A$. salmiana, was revealed by molecular analyses to be more closely related to varieties of $A$. mapisaga [58]. In the State of Mexico, Alfaro-Rojas et al. [26] found six traditional varieties of pulque agaves, while in the state of Michoacán five have been recorded [21]. According to the previous comparative data, the State of Hidalgo is the state with the highest diversity of managed agaves, in addition to hosting the wild variety from which some of the managed varieties and characteristics of the area have emerged, such as the traditional variety Xaminí.

Several authors agree that the genus Agave is highly variable, with high plasticity. This is due to the large number of ecotypes and clinotypes, as well as to the impact of factors such as arid environments and life history characteristics like pollination on Agave evolution [59,60,61]. In the case of pulque agaves, agrobiodiversity is due to various cultural motivations to keep these agaves in productive systems, and even though we can find high agrobiodiversity in the Mexican highlands, in other localities we notice a certain tendency of producers to switch to more productive crop systems with one or a few higher-yield varieties. There has also been an apparent increase in the intensity of management, with larger crop areas and increased use of agricultural technology such as the application of herbicides, though these trends need to be systematically corroborated.

Management and domestication of pulque agave. In Mexico there is a wide diversity of systems and intensity of management of pulque agaves [62]. In this study, the management systems of La Coyotera and El Cubo corresponded to Metepantles, from nahuatl metl: agave, pantli: rows, a traditional agroforestry system that consists of rows of agave interspersing plots of different plants, which maintain and conserve a high diversity of crops and native vegetation, such as Corriente or Cimarron agaves. The management of agaves has led to maintaining higher densities of traditional varieties that yield greater productivity in terms of quantity and quality of sap, as is the case of the Manso de Zoqui variety. However, producers maintain and protect other varieties even when they are not so profitable, as part of their interest in safeguarding part of their cultural heritage. The continuous selection of some of 
these agave varieties has led to individuals presenting a larger rosette size and less spinosity, as has been recorded in other works exploring domestication syndrome in pulque and mezcal agaves $[16,19,20,21,22,63)$. However, for pulque agaves, the characteristics associated with the quantity and quality of their sap when it is edible have not been studied, as has been referred to in the domestication syndrome proposed by Colunga-García-Marín et al. [16]. Producers identify differences in the production and quality of the sap of the traditional varieties identified in this work (Table 2), even so, it is pertinent to analyze in detail the daily and monthly production of sap of the traditional varieties, as well as to quantify their sweetness, acidity, density, and color, among other organoleptic characteristics, and confirm the tendencies of domestication in some species.

It has been proposed that producers traditionally select vigorous, vegetatively propagated suckers, and that these plants can be polyploid, which are maintained for generations through clones [64]. Polyploidy is an important event in the evolution of angiosperms and provides several advantages over their diploid relatives. For example, polyploids have greater adaptability and responses to extreme environments, greater tolerance to cold, resistance to pathogens, and genotypic plasticity to use new habitats. About half of the species of the genus Agave are polyploid [65], 40\% of the genus Littaea and $64.3 \%$ of the subgenus Agave [60]. For the species recorded in this research, it has been identified that they can exhibit various levels of ploidy. In A. americana, diploid (2x), tetraploid (4x), and hexaploid (6x) plants have been found. $A$. mapisaga presents sterile pentaploids (5x) [64, 66], and in $A$. salmiana tetraploid and hexaploid plants (6x) have been recorded [64]. This may be one of the reasons for the giant sizes in these species.

Genetic diversity and structure of pulque agaves. For the varieties and species in this study, the low levels of observed heterozygosity compared to expected heterozygosity and the high levels of inbreeding may be related to the presence of null alleles with frequencies greater than $8 \%$, which may increase the parameters of population differentiation such as $\mathrm{F}_{\mathrm{ST}}, \mathrm{F}_{\mathrm{IS}}$ and decrease genetic diversity [48]. On the other hand, the presence of null alleles may be due to the vegetative propagation of the same genotype in crops. It may also be due to the fact that we assumed the individuals to be diploid, even though polyploids are found in these species. It is therefore possible that we have underestimated the allelic richness and the presence of heterozygous individuals, identifying false homozygotes.

According to Eguiarte et al. [67], agaves exhibit similar levels of genetic diversity and population differentiation $\left(\mathrm{H}_{\mathrm{S}}=\right.$ $\left.0.190, F_{S T}=0.150\right)$ to monocot angiosperms in isoenzymes $\left(H_{E S}=0.158, G_{S T}=0.157 ;[68]\right)$ and $R A P D s\left(H_{P O P}=\right.$ $\left.0.190, \mathrm{G}_{\mathrm{ST}}=0.31 ;[69]\right)$. The diversity and genetic structure values we found were higher than those reported in those works, for the traditional varieties of pulque agave, the management categories, and the taxonomic identities. However, the molecular markers used in these studies were low-polymorphism markers, so comparisons must be made with care. On the other hand, Álvarez-Ríos et al. [21] evaluated the genetic diversity of five varieties of pulque agaves in Linderos management systems in Michoacán using nuclear microsatellites and found similar levels of species-level genetic diversity $(\mathrm{He})$ to our values, although their values for the species $A$. americana were higher than ours ([21]; $\mathrm{He}=0.527$ vs this study; $\mathrm{He}=0.290)$.

The hypothesis of higher genetic diversity in wild than cultivated populations of pulque agaves has been supported by several authors previously. Figueredo et al. [20] found that the cultivated species $A$. hookeri $(\mathrm{He}=0.485)$ presented lower levels of genetic diversity than its wild ancestor, $A$. inaequidens ( $\mathrm{He}=0.704)$. Similarly, Alfaro-Rojas et al. [26] found that genetic diversity was low for the cultivated species $A$. salmiana var. salmiana (Manso, $\mathrm{H}=0.121 ;$ Ayoteco, $\mathrm{H}=0.119$ ) and $A$. mapisaga (Carrizo, $\mathrm{H}=0.086$ ) in northeastern Mexico state using RAPD's, which compared to the high levels of diversity recorded in wild populations of $A$. salmiana ssp. crassispina in San Luis Potosí, using AFLP's $(\mathrm{Hs}=0.408)$. The low genetic diversity in pulque agaves may be due to intrinsic characteristics of the plant, as well as the fact that the crops have mostly been propagated vegetatively, possibly for the past few thousand years,

Page 19/30 
according to archaeological evidence. In addition, the fact that the management of plants eliminates the possibility of sexual reproduction, also prevents genetic recombination.

In the case of agaves used to produce traditional mescal, patterns of genetic diversity have been found to be the opposite of those reported for pulque agaves. This high diversity among cultivated varieties is due to the fact that there is a wide range of management systems, where traditional agroforestry systems (TAFS) are a reservoir for a high number of traditional varieties, morphological and genetic diversity, due to the frequent and constant introduction of plants from other sources in these systems, effective management practices such as the formation of seedbeds and the implementation of management plans to promote and maintain sexual reproduction. In addition, there is historical information that in some species of agaves the production of mezcal began approximately 400 years ago, with cultivation being an even more recent phenomenon (approximately 30 years) [20].

\section{Conclusions}

We found a high agrobiodiversity of agaves that are maintained in traditional agroforestry systems such as Metepantles and backyard gardens. The 12 varieties studied presented a great diversity in their form, which is a product of the varied environments where these agaves grow as well as the diverse cultural motivations of pulque producers to maintain diversity in their crops and management practices. As such, these systems should be considered productive spaces that maintain diversity, practices that should be maintained in other productive systems in the country. The species with the greatest diversity of forms was Agave salmiana, while the species that most clearly exhibited the domestication syndrome was $A$. mapisaga. The wild agave species showed high levels of genetic diversity, while the cultivated varieties exhibited low levels of diversity, probably due to vegetative propagation. Despite their low genetic diversity, wild varieties such as Corrientes or Cimarrones are found in the natural ecosystems of the Mezquital Valley, which eventually enrich the gene pool of the crops, with eventual introductions of plants to the plantations. Similarly, some crop plants "escape" (sexual reproduction), which in turn has maintained some diversity of cultivated plants.

\section{Declarations}

\section{Ethics approval and consent to participate}

At the beginning of the research, we established contact with authorities and people in the communities where the research was carried out, to whom we presented the study project and obtained their permission.

\section{Consent for publication}

Not applicable.

\section{Availability of data and materials}

All data analyzed during this study are included in this published article.

\section{Competing interests}

No competing interests

\section{Funding}


This work was funded by the first author and is part of the project Cátedras CONACYT-1245-Genética de la conservación en el estado de Hidalgo.

\section{Authors' contributions}

CJFU conceived and designed the study, wrote the manuscript, got financial support for carrying out the research, designed the methodological approach for the morphological and genetic study, did the fieldwork and analyzed the data.

GDAR helped with fieldwork, analyzed the ethnobotanical and morphological data, and wrote part of the manuscript.

MAGM helped with fieldwork and the standardization and genetic analyses and wrote part of the manuscript.

POA helped with financial and equipment support for genetic analysis, the fieldwork, statistical analyses, and wrote part of the manuscript.

\section{Acknowledgements}

We thank the agave producers and managers from the localities of El Cubo, Cardonal and El Rancho La Coyotera, Zacualtipán de Ángeles, for their support and willingness to collaborate in this project. We thank Ilse Ortega, Alfredo Sánchez González, and Mariana Vallejo Ramos for help in the field. We thank Dr. Fernando Rosas Pacheco, Cuerpo Académico de Ecología and Apoyo al Fortalecimiento y Desarrollo de la Infraestructura Científica y Tecnológica 2015. INFR-2015-01. Proyecto 252807, for lending equipment for the genetic analyses.

\section{References}

1. APG III 2009. An update of the Angiosperm Phylogeny Group classification for orders and families of flowering plants: APG III. Botanical Journal of the Linnean Society, 61: 105-121.

2. APG IV. 2016. An update of the Angiosperm Phylogeny Group classification for the orders and families of flowering plants: APG IV. Botanical Journal of the Linnean Society 181(1): 1-20. DOI: https://doi.org/10.1111/boj.12385

3. García-Mendoza AJ, Franco-Martínez I, Sandoval-Gutiérrez D. 2019. Cuatro especies nuevas de Agave (Asparagaceae, Agavoideae) del sur de México. Acta Botánica Mexicana,126. doi: https://doi.org/10.21829/abm126.2019.1461

4. Torres-García, I., Rendón-Sandoval, F. J., Blancas, J., Casas, A., y Moreno-Calles, A. I. 2019. The genus Agave in agroforestry systems of Mexico. Botanical Sciences, 97: 263-290.

5. Gentry, H. S. 1982. Agaves of Continental North America. Tucson: The University of Arizona Press.

6. Rocha, M. 2006. Ecología evolutiva comparada en cinco especies de Agave. Tesis de doctorado. Posgrado de Ciencias Biológicas, UNAM, México, D.F., México.

7. Scheinvar, Enrique \& Eguiarte, Luís \& Jiménez-Sierra, Cecilia \& Matias-Palafox, Maria \& Munive, Martha \& Arzate, Karla \& Salazar, Roberto \& Pineda, Jaime \& Olson, Mark \& Abreu, Nuria \& Trejo, Laura \& González-González, Andrea \& Tamariz, Niza \& Chauvet, Rodrigo. (2008). Agaves y Cactáceas de Metztitlán: Ecología, Evolución y Conservación.

8. MacNeish RS. A summary of the subsistence. In: Byers D, editor. The Prehistory of the Tehuacan Valley. Volume 1: Environment and Subsistence. Austin: University of Texas Press; 1967:290-310. 
9. Callen EO. Analysis of the Tehuacan coprolites. In: Byers D, editor. The Prehistory of the Tehuacan Valley. Volume 1: Environment and Subsistence. Austin: University of Texas Press; 1967: 261-289.

10. Smith EC. Plant Remains. In: Byers D, editor. The Prehistory of the Tehuacan Valley. Volume 1: Environment and Subsistence. Austin: University of Texas Press; 1967:220-255.

11. Goncalves de Lima O. El maguey y el pulque en los códices mexicanos. México: FCE; 1986.

12. Álvarez-Palma A, Canssiano G., Villa-Kamel A. La explotación del maguey pulquero en la zona de Metztitlan: datos etnográficos y arqueológicos. Dimensión Antropológica. 1998; 13: 7-30.

13. Pickersgill, B. (2007). Domestication of plants in the Americas: insights from Mendelian and molecular genetics. Annals of botany, 100: 925-940.

14. Casas, A., Otero-Arnaiz, A., Pérez-Negrón, E., and Valiente-Banuet, A. 2007. In situ management and domestication of plants in Mesoamerica. Annals of botany, 100: 1101-1115.

15. Casas, Alejandro \& Camou, Andrés \& Otero-Arnaiz, Adriana \& Rangel-Landa, Selene \& Cruse-Sanders, Jennifer \& Solis-Rojas, Leonor \& Torres-García, Ignacio \& Delgado, América \& Moreno Calles, Ana \& Vallejo, Mariana \& Rodríguez, Susana \& Vázquez, José \& Parra, Fabiola \& Berenice, Farfan \& Aguirre-Dugua, Xitlali \& ArellanesCancino, Yaaye \& Pérez-Negrón, Y. (2014). Manejo tradicional de biodiversidad y ecosistemas en Mesoamérica: el Valle de Tehuacán. Investigación Ambiental. Ciencia y Política Pública. 6. 23-44.

16. Colunga-GarcíaMarín, P., Zizumbo-Villarreal, D., Torres, I., Casas, A., Figueredo Urbina, C. J., Rangel-Landa, Selene Delgado-Lemus, A., Carrillo-Galván, G. 2017. Los agaves y las prácticas mesoamericanas de aprovechamiento, manejo y domesticación. En: Domesticación en el Continente Americano Vol. 2.

17. Colunga-GarcíaMarín, P., Estrada-Loera, E., \& May-Pat, F. 1996. Patterns of morphological variation, diversity, and domestication of wild and cultivated populations of Agave in Yucatan, Mexico. American Journal of Botany, 83(8), 1069-1082.

18. Carrillo-Galván, M. G. 2011. Domesticación de agaves productores de fibra en el centro-occidente de México: una aproximación etnobotánica y morfológica (Doctoral dissertation, MSc. Thesis, Centro de Investigaciones Científicas de Yucatán AC).

19. Vargas-Ponce, O., Zizumbo-Villarreal, D., \& Marin, P. C. G. (2007). In situ diversity and maintanenace of traditional Agave landraces used in spirits production in West-Central Mexico. Economic botany, 61: 362.

20. Figueredo-Urbina CJ, Casas A, Torres-García I. Morphological and genetic divergence between Agave inaequidens, $A$. cupreata and the domesticated $A$. hookeri. Analysis of their evolutionary relationships. PLoS ONE. 2017; 12(11). doi:10.1371/journal. pone.0187260.

21. Álvarez-Ríos, G.D., Pacheco-Torres, F., Figueredo-Urbina, C.J., and Casas, A. 2020. Management, morphological and genetic diversity of domesticated agaves in Michoacán, México. Journal of Ethnobiology and Ethnomedicine, 16: 3.

22. Mora-López J, Reyes-Agüero L, Flores-Flores JA, Peña-Valdivia JL, Beatriz C, Aguirre-Rivera JR. Variación morfológica y humanización de la sección Salmianae del género Agave. Agrociencia. 2011;45(4):465-477.

23. Castro-Díaz, A.S. and Guerrero-Beltrán, J.A. 2013. El agave y sus productos. Temas selectos de Ingeniería de alimentos, 7: 53-61.

24. Álvarez-Duarte, M.C., García-Moya, E., Suárez-Espinosa, J., Luna-Cavazos, M. and Rodríguez-Acosta, M. 2018. Conocimiento tradicional, cultivo y aprovechamiento del maguey pulquero en los municipios de Puebla y Tlaxcala. Polibotánica, 45: 205-222.

25. Castañeda-Nava, J.J., Rodríguez-Domínguez, J.M., Camacho-Ruiz, R.M., Gallardo-Valdez, J., Villegas-García, E. and Gutiérrez-Mora, A. 2019. Morphological comparison among populations of Agave salmiana Otto ex Salm- 
Dyck (Asparagaceae), a species used for mezcal production in Mexico. Flora, 255: 18-23.

26. Alfaro-Rojas, G., Legaria Solano, J.P. and Rodríguez Pérez, J.E. 2007. Genetic diversity in populations of pulquero agaves (Agave spp.) in northeastern Mexico state. Revista Fitotecnia Mexicana, 30: 1-12.

27. Lara-Ávila, J.P. and Alpuche-Solís, Á.G. 2016. Análisis de la diversidad genética de agaves mezcaleros del centro de México. Revista fitotecnia mexicana, 39: 323-330.

28. Lindsay, D.L., Swift, J.F., Lance, R.F. and Edwards, C.E. 2018. A comparison of patterns of genetic structure in two co-occurring Agave species (Asparagaceae) that differ in the patchiness of their geographical distributions and cultivation histories. Botanical Journal of the Linnean Society, 186: 361-373.

29. Servicio de Información Agroalimentaria y Pesquera (SIAP). 2020. Estadística de Producción Agrícola. Disponible en: http://infosiap.siap.gob.mx/gobmx/datosAbiertos_a.php

30. Anderson, R. K., Calvo, J., Serrano, G., \& Payne, G. C. (2009). Study of the state of nutrition and eating habits of autonomous communities in Mezquital Valley, Mexico. Salud Pública de México, 51, 657-674.

31. Reyes-Agüero, J., Valdivia, C.B, Rivera, J. and López, L.M. 2019. Infraspecific variation of Agave mapisaga Trel. and $A$. salmiana Otto ex Salm-Dyck. (Asparagaceae) related to ancestral usages at the Hñähñu region in central Mexico. Agrociencia, 53: 563-579.

32. INEGI. 1992. Síntesis geográfica del estado de Hidalgo.

33. Morrone, J.J. 2001. Biogeografía de América Latina y el Caribe. Volumen 3, Manuales y tesis de la Sociedad Entomológica Aragonesa, Zaragoza, España.

34. Munsell, A.H. (2012). A color notation. Munsell color company

35. R Development Core Team. (2010). R: A language and environment for statistical computing. (Vienna, Austria: R Foundation for Statistical Computing).

36. JMP®, Version 8. SAS Institute Inc., Cary, NC.1989-2007.

37. Neubig KM, Whitten WM, Abbott JR, Elliott S, Soltis DE, Soltis PS. 2014. Variables affecting DNA preservation in archival DNA specimens. In: Applequist WL, Campbell LM, eds. DNA banking in the 21st century: proceedings of the U.S. workshop on DNA banking. St. Louis: The William L. Brown Center at the Missouri Botanical Garden. 81136

38. Doyle, J.J., Doyle, J.L. 1987. A rapid DNA isolation procedure for small quantities of fresh leaf tissue. Phytochemical Bulletin 19: 11-15.

39. Lindsay, D.L., Edwards, C.E., Jung, M.G., Bailey, P., and Lance, R.F. 2012. Novel microsatellite loci for Agave parryi and cross-amplification in Agave palmeri (Agavaceae). American journal of botany 99: 295-297.

40. Byers, C., Maughan, P.J., Clouse, J. and Stewart, J.R. 2014. Microsatellite primers in Agave utahensis (Asparagaceae), a keystone species in the Mojave Desert and Colorado Plateau. Applications in plant sciences 2: $140-147$.

41. Lazar, I. and Lazar, I. 2010. Gel Analyzer 2010a: Freeware 1D gel electrophoresis image analysis software.

42. Van Oosterhout C, Hutchinson WF, Wills DP, Shipley P. 2004. MICRO-CHECKER: software for identifying and correcting genotyping errors in microsatellite data. Molecular Ecology Notes, 4: 535-538.

43. Chakraborty, R., Andrade, M. D., Daiger, S. P., \& Budowle, B. 1992. Apparent heterozygote deficiencies observed in DNA typing data and their implications in forensic applications. Annals of human genetics, 56: 45-57.

44. Paradis E. 2010. Pegas: An R Package for Population Genetics with an Integrated-Modular Approach. Bioinformatics, 26: 419-420. 
45. R Core Team. 2019. R: A Language and Environment for Statistical Computing. Vienna: R Foundation for Statistical Computing. Available at http://www.R-project.org/.

46. Excoffier, L., \& Lischer, H. E. 2010. Arlequin Suite Ver 3.5: A New Series of Programs to Perform Population Genetics Analyses Under Linux and Windows. Molecular Ecology Resources, 10: 564-567.

47. Kamvar, Z. N., Tabima, J. F., \& Grünwald, N. J. 2014. Poppr: An R Package for Genetic Analysis of Populations with Clonal, Partially Clonal, and/or Sexual Reproduction. PeerJ, 2: 281-14.

48. Chapuis MP, Estoup A. 2006. FreeNa: microsatellite null alleles and estimation of population differentiation. Molecular biology and evolution, 24: 621-631.

49. Chybicki, I.J. and Burczyk, J. 2009. Simultaneous estimation of null alleles and inbreeding coefficients. Journal of Heredity, 100: 106-113

50. Nei, M and Takezaki N. 1983. Estimation of genetic distances and phylogenetic trees from DNA analysis. Proc 5th World Cong Genet Appl Livstock Prod, 21: 405-412.

51. Takezaki, N., Nei, M. and Tamura, K. 2010. POPTREE2: Software for constructing population trees from allele frequency data and computing other population statistics with Windows interface. Molecular biology and evolution, 27(4), 747-752.

52. Pritchard JK, Stephens M, Donnelly P. 2000. Inference of population structure from multilocus genotype data. Genetics155: 945-959.

53. Falush D, Stephens M, Pritchard JK. 2007. Inference of population structure using multilocus genotype data: dominant markers and null alleles. Molecular Ecology Notes, 7: 574-578.

54. Evanno G, Regnaut S, Goudet J. 2005. Detecting the number of clusters of individuals using the software STRUCTURE: a simulation study. Molecular Ecology, 14: 2611-2620.

55. Li Y, Liu J. 2018. Structure Selector: A web-based software to select and visualize the optimal number of clusters using multiple methods. Molecular Ecology Resources, 18: 176-177.

56. Jombart T. 2008. “adegenet: A R package for the multivariate analysis of genetic markers". Bioinformatics, 24: 1403-1405.

57. Colunga-GarcíaMarín, P., Zizumbo-Villarreal, D., \& Martínez-Torres, J. (2007). Tradiciones en el aprovechamiento de los agaves mexicanos: una aportación a la protección legal y conservación de su diversidad biológica y cultural. En lo ancestral hay futuro: del tequila, los mezcales y otros agaves, 248.

58. Trejo, L., Reyes, M., Corte s-Toto, D., Romano-Grande, E., \& Muñoz-Camacho, L. L. (2020). Morphological diversity and genetic relationships in pulque production agaves in Tlaxcala, Mexico, by means of unsupervised learning and gene sequencing analysis. Front. Plant Sci. 11: 524812. doi: 10.3389/fpls.

59. Granados, S. D. (1993). Los agaves en México (No. 633.577 G7).

60. Palomino, G., Martínez, J., Cepeda-Cornejo, V., \& Pimienta-Barrios, E. 2012. Nuclear genome size and cytotype analysis in Agave cupreata Trel. \& Berger (Agavaceae). Caryologia, 65: 281-294.

61. Jiménez-Barron O, García-Sandoval R, Magallón S, García-Mendoza A, Nieto-Sotelo J, Aguirre-Planter E and Eguiarte LE (2020) Phylogeny, Diversification Rate, and Divergence Time of Agave sensu lato (Asparagaceae), a Group of Recent Origin in the Process of Diversification. Front. Plant Sci. 11:536135. doi: 10.3389/fpls.2020.536135

62. Álvarez-Ríos, GD. Figueredo-Urbina, CJ, Casas, A. 2020. Sistemas de manejo de maguey pulquero en México. Etnobiología 18(2): 3-23. 
63. Cabrera-Toledo, D., Vargas-Ponce, O., Ascencio-Ramírez, S., Valadez-Sandoval, L. M., Pérez-Alquicira, J., MoralesSaavedra, J., \& Huerta-Galván, O. F. (2020). Morphological and genetic variation in monocultures, forestry systems and wild populations of Agave maximiliana of western Mexico: implications for its conservation. Frontiers in plant science, $11,817$.

64. Palomino et al. 2009. (Libro en lo ancestral)

65. Goldblatt, P. (1980). Polyploidy in angiosperms: monocotyledons. In Polyploidy (pp. 219-239). Springer, Boston, MA.

66. Robert et al. 2018

67. Eguiarte, L. E., Aguirre-Planter, E., Aguirre, X., Colín, R., González, A., Rocha, M., ... \& Souza, V. (2013). From isozymes to genomics: population genetics and conservation of Agave in México. The Botanical Review, 79(4), 483-506.

68. 68. Hamrick, J. L., \& Godt, M. W. (1996). Effects of life history traits on genetic diversity in plant species. Philosophical Transactions of the Royal Society of London. Series B: Biological Sciences, 351(1345), 12911298.

69. Nybom, H., \& Bartish, I. V. (2000). Effects of life history traits and sampling strategies on genetic diversity estimates obtained with RAPD markers in plants. Perspectives in plant ecology, evolution, and systematics, 3(2), 93-114.

\section{Figures}



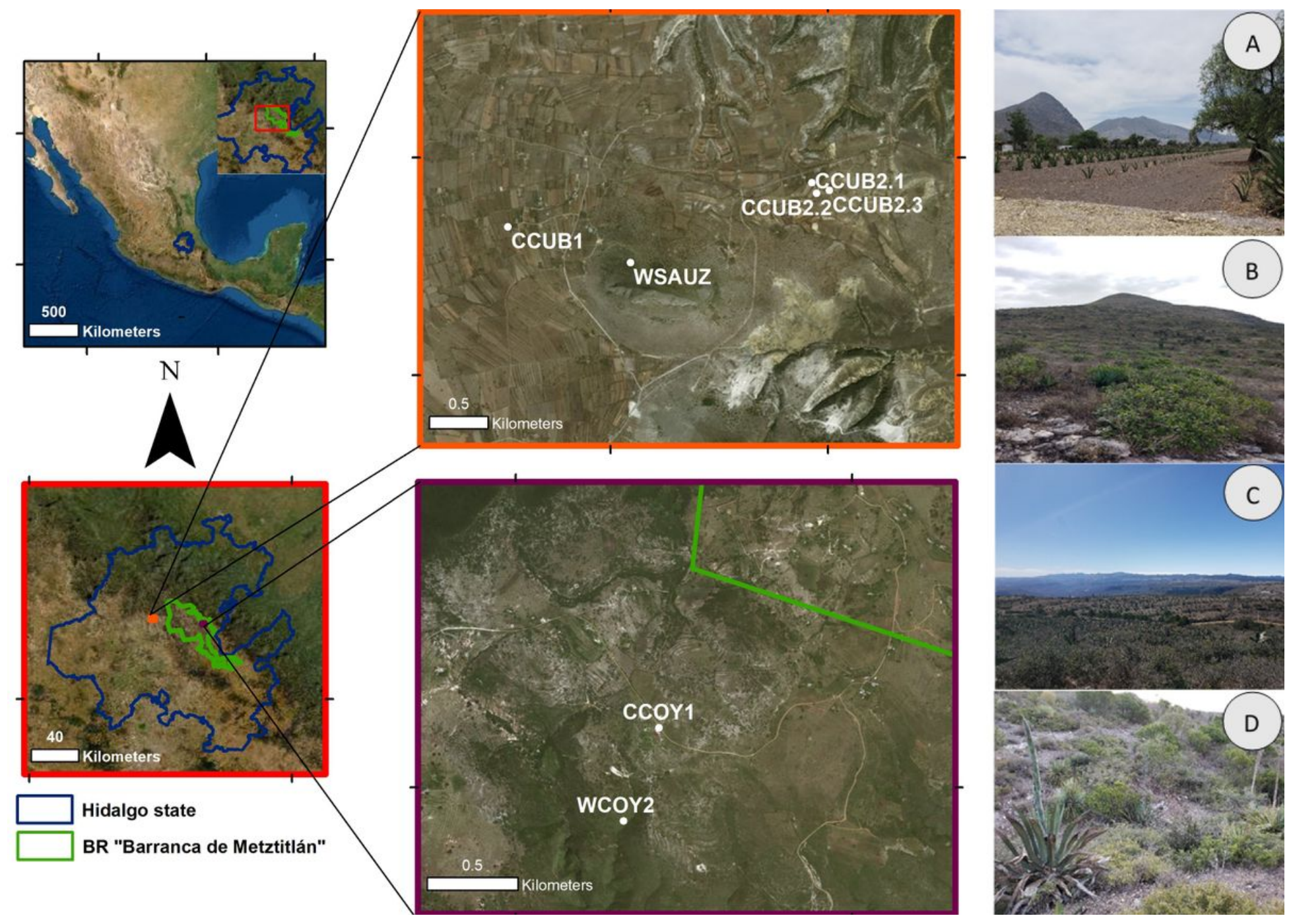

Figure 1

Map of the localities studied in the state of Hidalgo. A) view of agave crops as living fences and in rows interspersed with other crops (CCUB), B) Cerro Blanco or El Fraile, where wild agaves were measured (WSAUZ), C) Panoramic view of the crops in Jilas in La Coyotera (CCOY1), D) Xeric scrubland at La Coyotera in the Barranca de Metztitlán Biosphere Reserve, where wild individuals of Agave salmiana ssp. crassispina can be seen (WCOY2). Note: The designations employed and the presentation of the material on this map do not imply the expression of any opinion whatsoever on the part of Research Square concerning the legal status of any country, territory, city or area or of its authorities, or concerning the delimitation of its frontiers or boundaries. This map has been provided by the authors. 

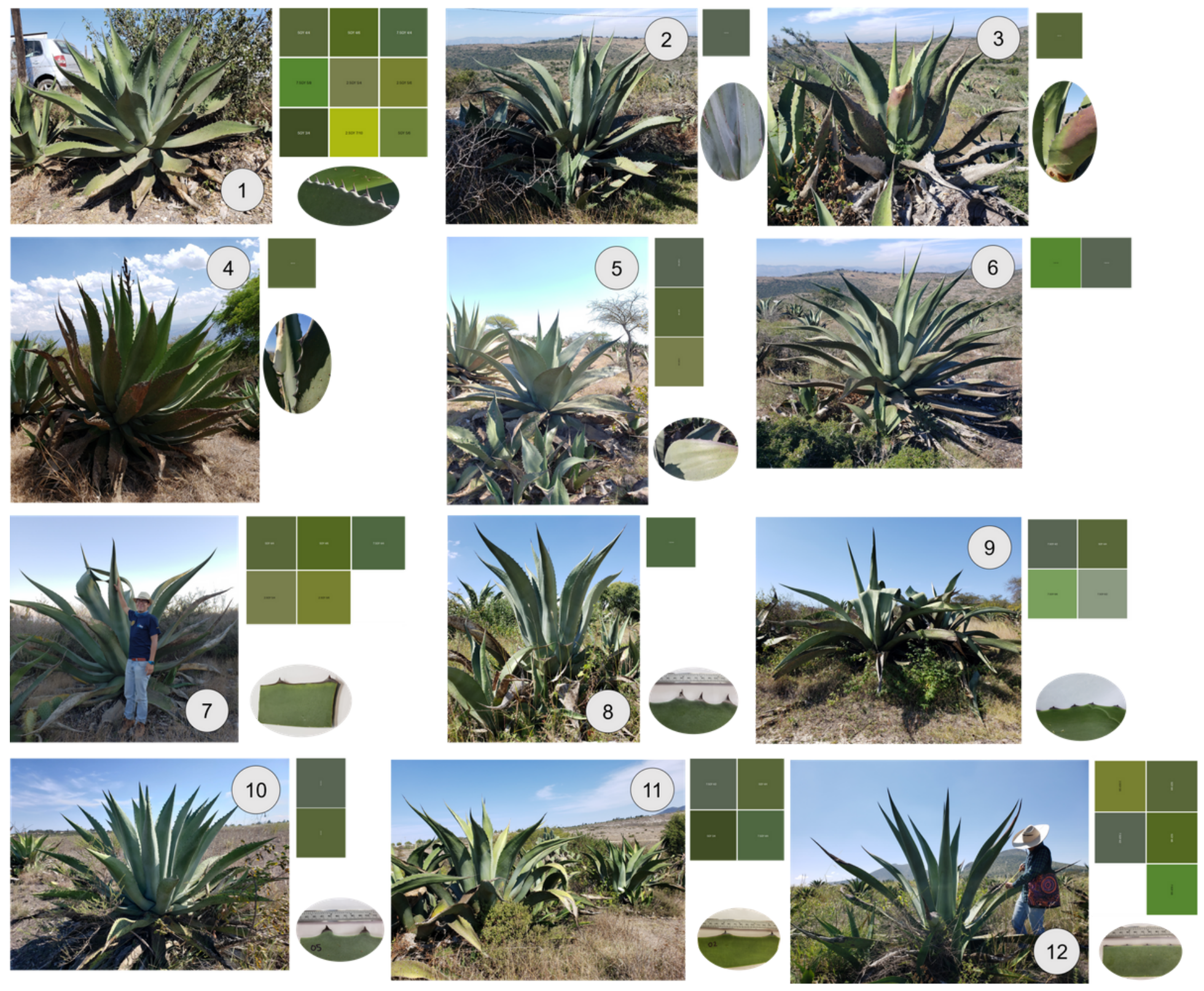

Figure 2

Traditional varieties of pulque agave recorded in the study localities in the state of Hidalgo 1) Corriente, 2) Corriente cenizo, 3) Corriente colorado 4) Corriente-Espina china, 5) Corriente-Penca ancha, 6) Corriente penca larga, 7) Manso de Zoqui, 8) Xaminí, 9) Poblano, 10) Guanté, 11) Mutá, 12) Penca Larga. 

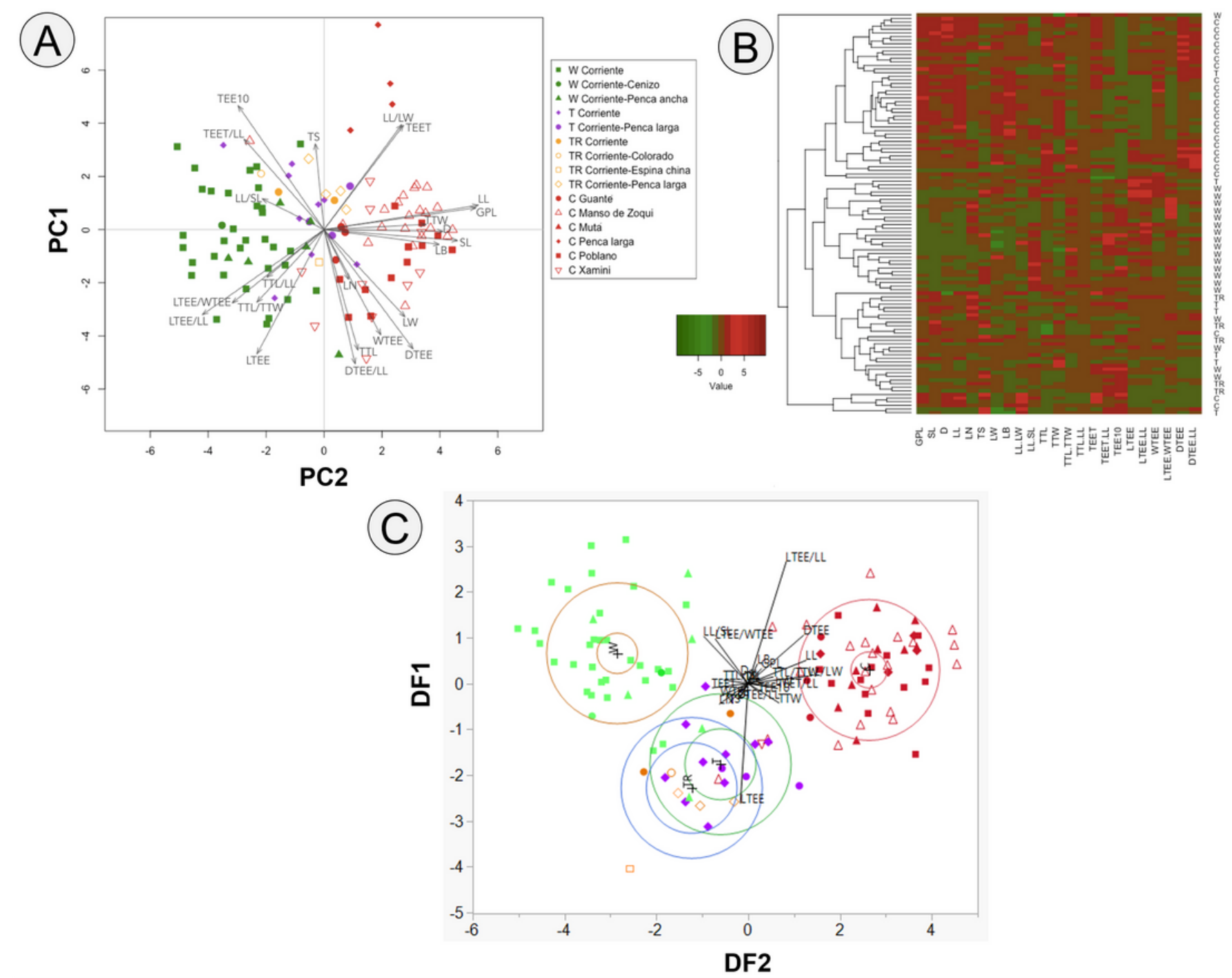

Figure 3

A) Principal components analysis (PCA) according to the 23 morphological variables measured in the twelve traditional varieties of Agave in the studied localities in Hidalgo state. The wild varieties are in green, tolerated in purple, transplanted in yellow and cultivated in red. B) Heatmap of management categories of agave and morphological traits. The cultivated agaves are in the upper part of the dendrogram, the wild in the middle, and the bottom part contains a mixture of all categories. Characteristics related to the gigantism of the individual are associated with cultivated varieties and increased thorniness was associated with wild varieties. 

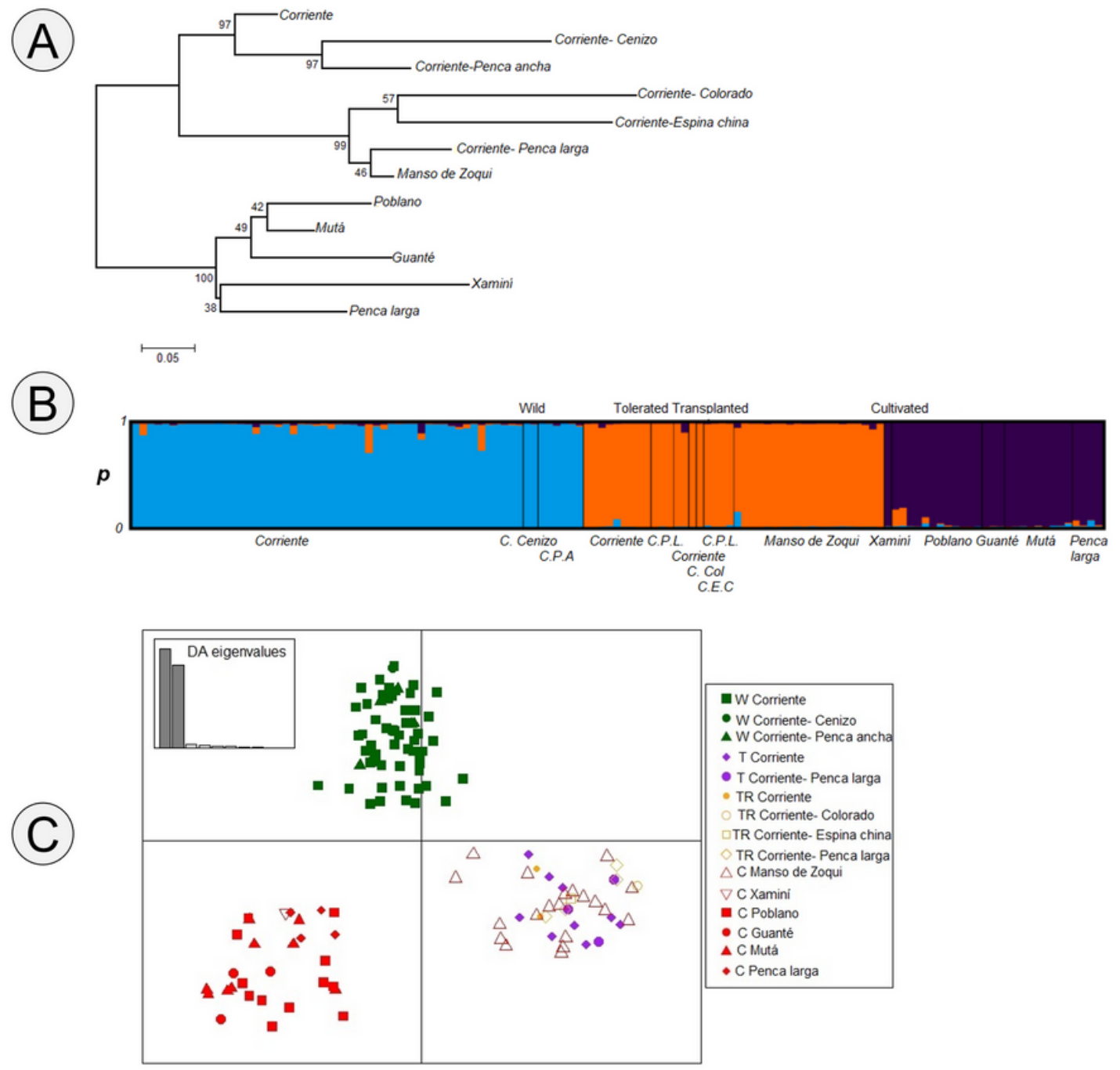

Figure 4

Neighbor-joining tree constructed using Nei's genetic distances between 12 traditional varieties of Agave in the Hidalgo state. The numbers shown are bootstrap probabilities based on 10000 replicates. The length of the bar is equal to a genetic distance of 0.05 .

\section{Image not available with this version}

Figure 5 
A) Bayesian model-based clustering STRUCTURE analysis as inferred at $\mathrm{K}=3$ (C.Cen: Corriente-Cenizo; C.P.A.: Corriente-Penca ancha; C.P.L.: Corriente-Penca larga; C.Col: Corriente-Colorado; C.E.C.: Corriente-Espina china), B) Multivariate approach DAPC, the eigenvalues from the Discriminant Analysis are shown. 